\title{
Optically Pure Calix[6]tris-ammoniums: Syntheses and Host- guest Properties toward Neutral Guests
}

\author{
Ulrich Darbost, Xianshun Zeng, Michel Giorgi and Ivan Jabin*
}

\section{Supporting Information}

All the NMR spectra have been recorded in $\mathrm{CDCl}_{3}$.

Figure S1. ${ }^{1} \mathrm{H}$ NMR spectrum $(300 \mathrm{MHz}, \mathrm{rt})$ of $\mathbf{3}$.

Figure S2. ${ }^{1} \mathrm{H}$ NMR spectrum $(300 \mathrm{MHz}, \mathrm{rt})$ of 4.

Figure S3. ${ }^{1} \mathrm{H}$ NMR spectrum $(300 \mathrm{MHz}, 330 \mathrm{~K})$ of 6.

Figure S4. ${ }^{1} \mathrm{H}$ NMR spectrum $(300 \mathrm{MHz}, 330 \mathrm{~K})$ of 7.

Figure S5. ${ }^{1} \mathrm{H}$ NMR spectrum $(300 \mathrm{MHz}, \mathrm{rt})$ of 8 .

Figure S6. ${ }^{1} \mathrm{H}$ NMR spectrum $(300 \mathrm{MHz}, 330 \mathrm{~K})$ of 9.

Figure S7. ${ }^{1} \mathrm{H}$ NMR spectrum $(300 \mathrm{MHz}, \mathrm{rt})$ of $\mathbf{1 0}$.

Figure S8. ${ }^{1} \mathrm{H}$ NMR spectra $(300 \mathrm{MHz}, 223 \mathrm{~K})$ of $10 \cdot 3 H^{+} \supset(-)$-propane-1,2-diol and $10 \cdot 3 H^{+} \supset( \pm)$-propane-1,2-diol.

Figure S9. ${ }^{13} \mathrm{C}$ NMR spectrum $(75 \mathrm{MHz}, \mathrm{rt})$ of 3 .

Figure S10. ${ }^{13} \mathrm{C}$ NMR spectrum $(75 \mathrm{MHz}, \mathrm{rt})$ of 4 .

Figure S11. ${ }^{13} \mathrm{C}$ NMR spectrum $(75 \mathrm{MHz}, \mathrm{rt})$ of 5 .

Figure S12. ${ }^{13} \mathrm{C}$ NMR spectrum $(75 \mathrm{MHz}, \mathrm{rt})$ of 8 .

Figure S13. HMQC spectrum ( $300 \mathrm{MHz}, \mathrm{rt})$ of $\mathbf{3}$.

Figure S14. HMQC spectrum (300 MHz, rt) of 4.

Figure S15. HMQC spectrum ( $300 \mathrm{MHz}, \mathrm{rt})$ of 5.

Figure S16. HMQC spectrum (300 MHz, rt) of 7.

Figure S17. HMQC spectrum (300 MHz, rt) of 8.
Figure S18. HMQC spectrum ( $300 \mathrm{MHz}, 330 \mathrm{~K})$ of 9. Figure S19. HMQC spectrum $(300 \mathrm{MHz}, \mathrm{rt})$ of $\mathbf{1 0}$.

Figure S20. HMBC spectrum $(300 \mathrm{MHz}, \mathrm{rt})$ of 7 .

Figure S21. HMBC spectrum (300 MHz, $330 \mathrm{~K})$ of 9.

Figure S22. HMBC spectrum (300 MHz, rt) of 10.

Figure S23. COSY spectrum $(300 \mathrm{MHz}, \mathrm{rt})$ of $\mathbf{3}$.

Figure S24. COSY spectrum $(300 \mathrm{MHz}, \mathrm{rt})$ of 4.

Figure S25. COSY spectrum ( $300 \mathrm{MHz}, 330 \mathrm{~K})$ of 6.

Figure S26. COSY spectrum $(300 \mathrm{MHz}, \mathrm{rt})$ of 7.

Figure S27. COSY spectrum ( $300 \mathrm{MHz}, 330 \mathrm{~K})$ of 9.

Figure S28. COSY spectrum $(300 \mathrm{MHz}, \mathrm{rt})$ of $\mathbf{1 0}$.

Figure S29. NOESY spectrum $(300 \mathrm{MHz}, \mathrm{rt})$ of $\mathbf{1 0}$.

Figure S30. NOESY spectrum $(300 \mathrm{MHz}, \mathrm{rt})$ of $10 \cdot 3 H^{+} \supset$ DMSO.

Figure S31. Crystal structure of $\mathbf{1 0} \cdot 3 \mathrm{H}^{+} \supset \mathrm{CH}_{3} \mathrm{CN}$ displaying the main intermolecular $\mathrm{H}$-bond interactions within the unit cell.

Page S32. General Experimental Procedures.

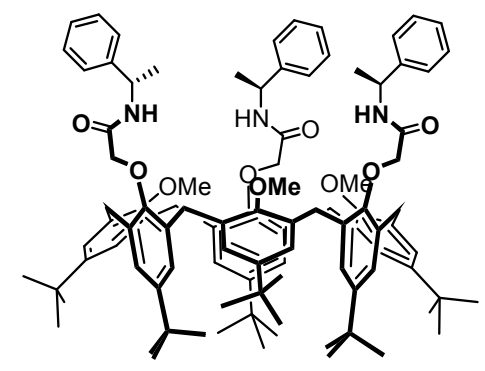

3

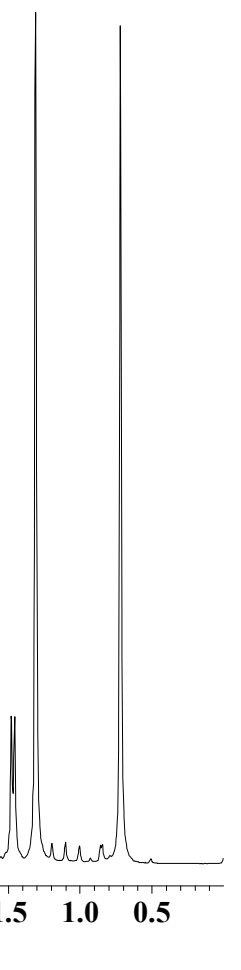

Figure S1. ${ }^{1} \mathrm{H}$ NMR spectrum $\left(300 \mathrm{MHz}, \mathrm{CDCl}_{3}\right.$, rt) of 3. 


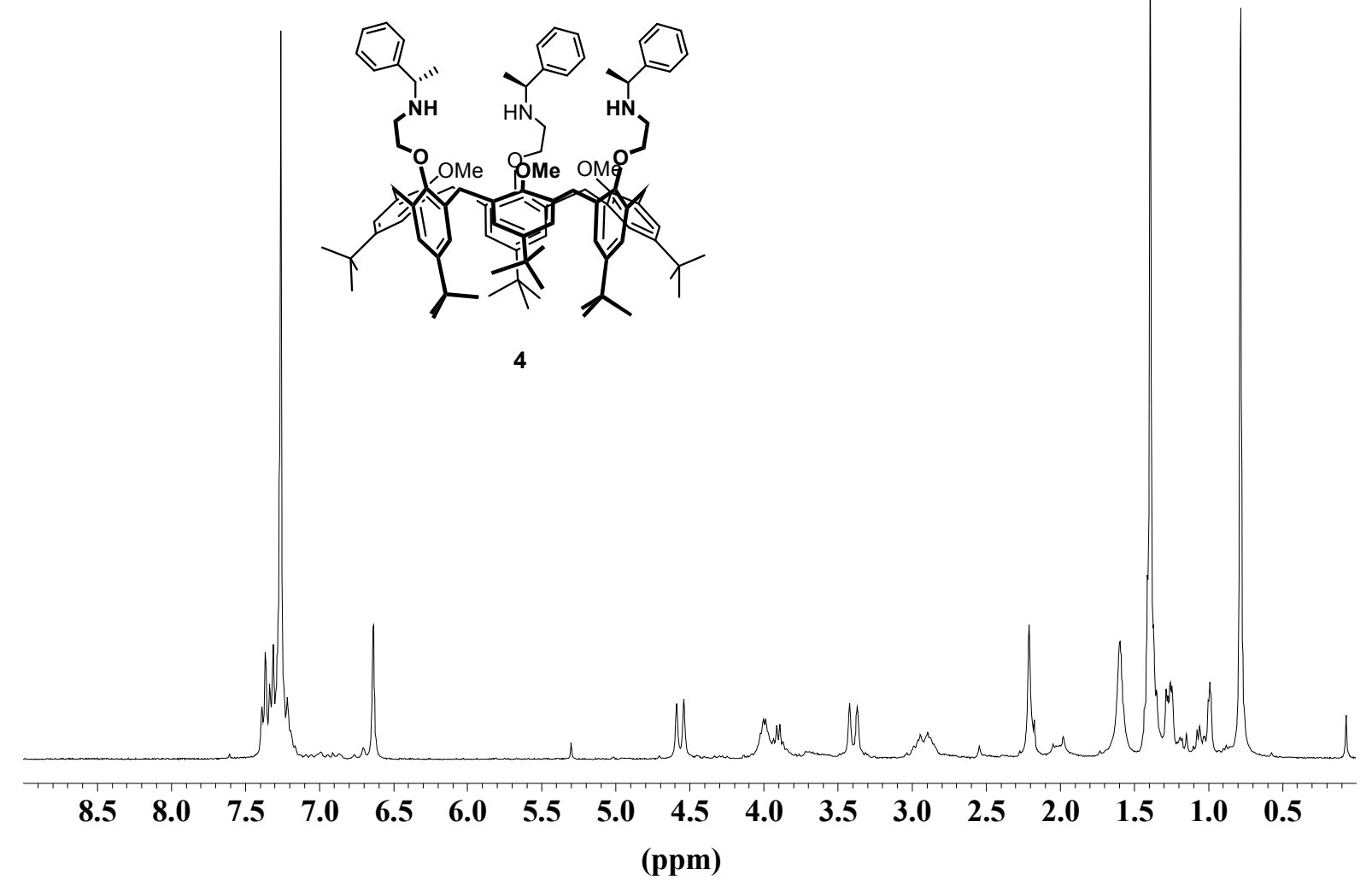

Figure S2. ${ }^{1} \mathrm{H}$ NMR spectrum $(300 \mathrm{MHz}, \mathrm{rt})$ of 4. 


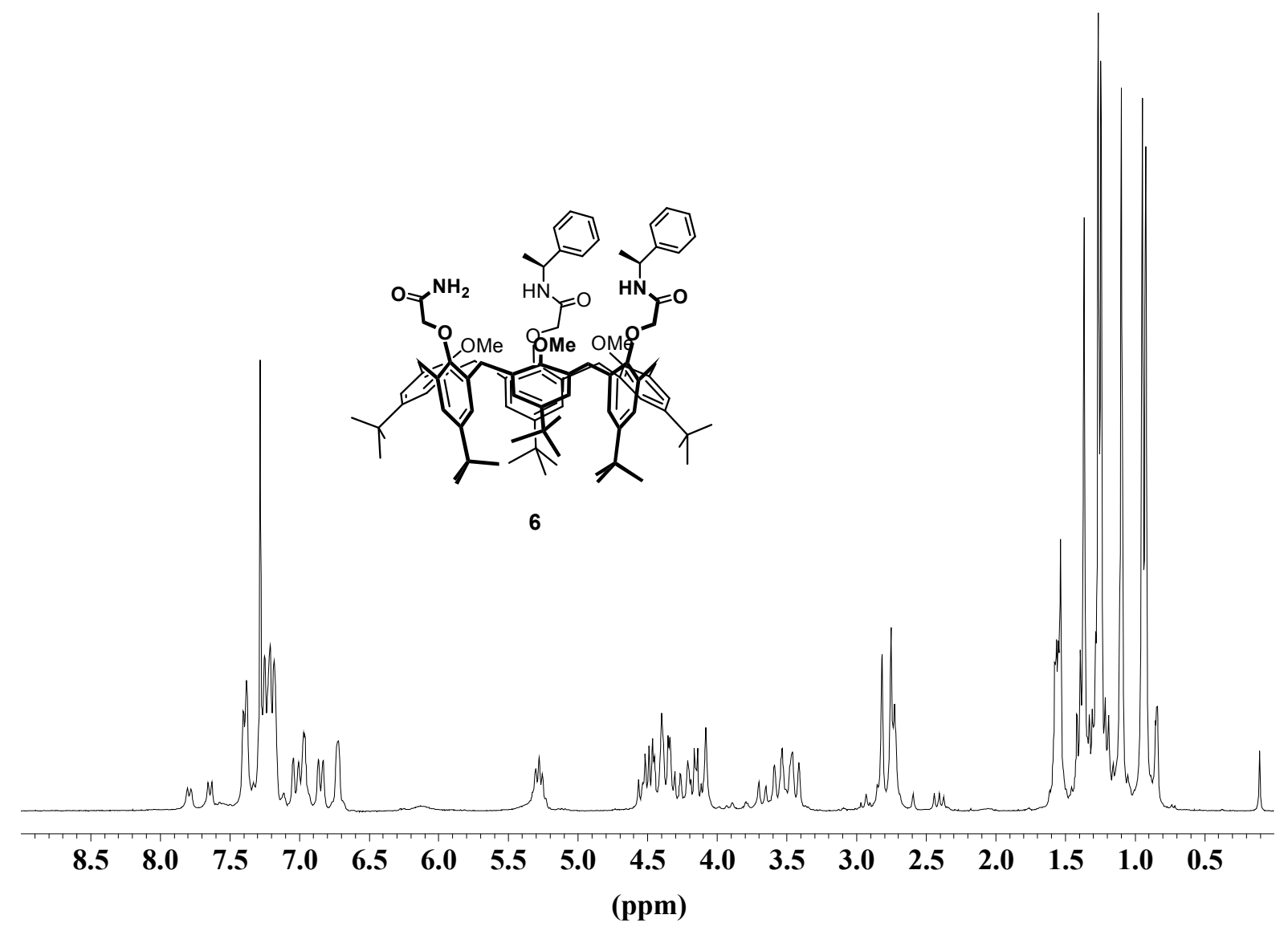

Figure S3. ${ }^{1} \mathrm{H}$ NMR spectrum $(300 \mathrm{MHz}, 330 \mathrm{~K})$ of 6 . 


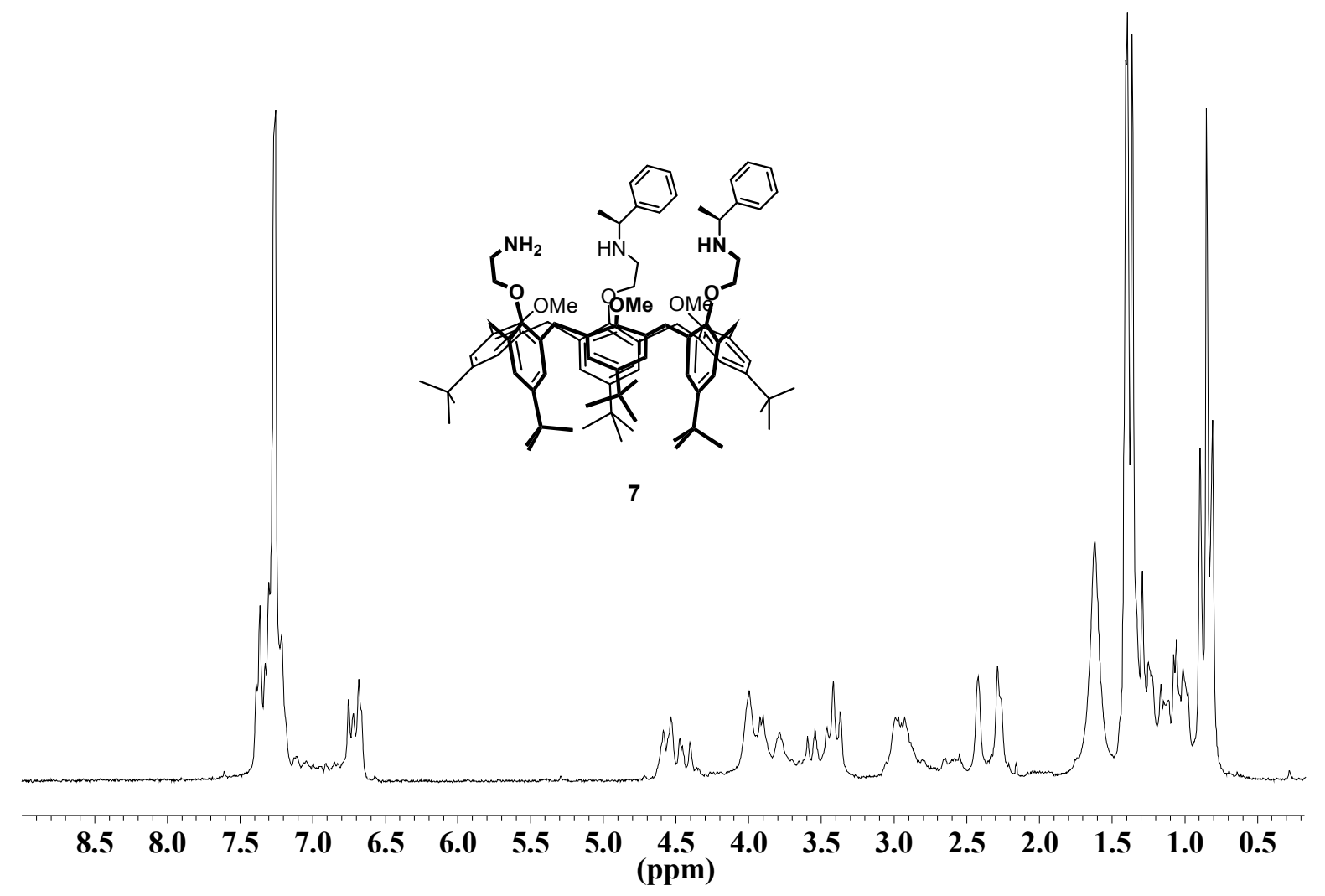

Figure S4. ${ }^{1} \mathrm{H}$ NMR spectrum $(300 \mathrm{MHz}, 330 \mathrm{~K})$ of 7. 


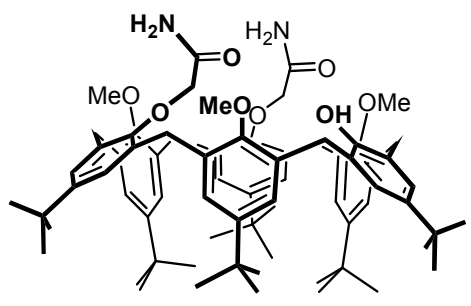

8

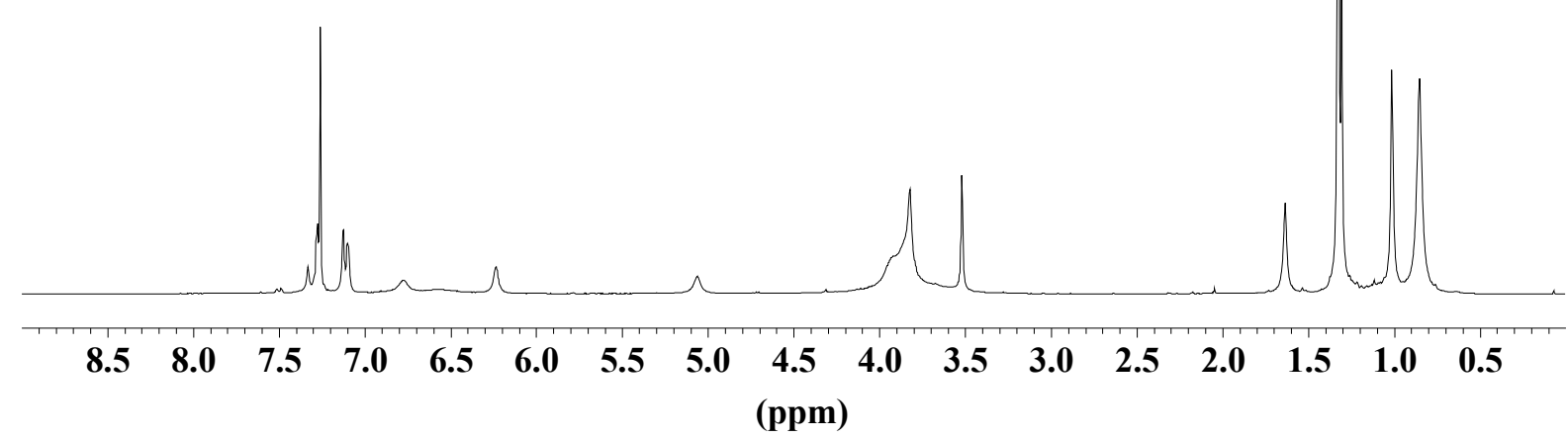

Figure S5. ${ }^{1} \mathrm{H}$ NMR spectrum $(300 \mathrm{MHz}, \mathrm{rt})$ of $\mathbf{8}$. 


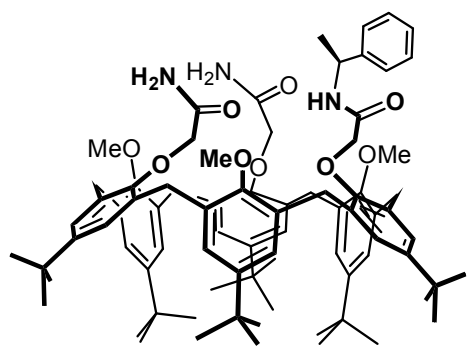

9

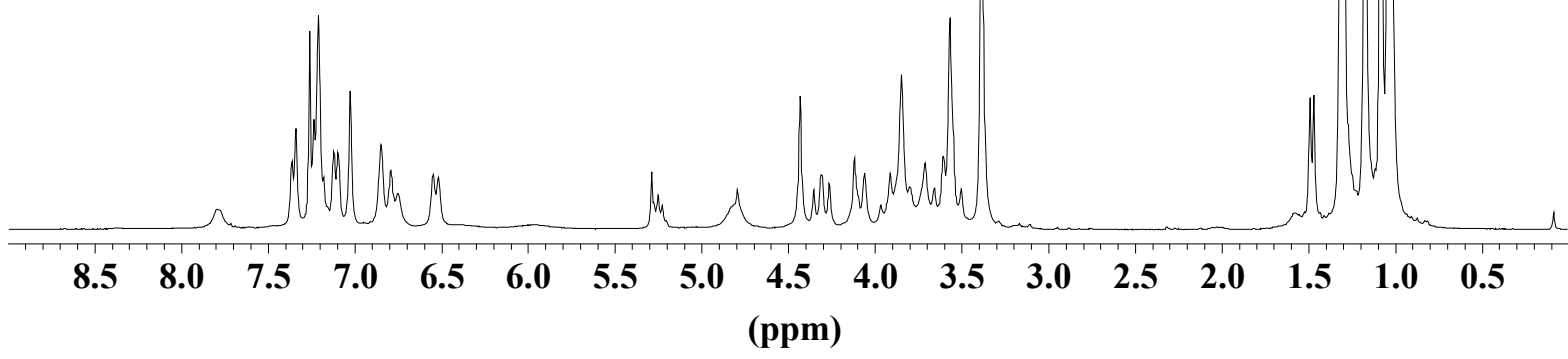

Figure S6. ${ }^{1} \mathrm{H}$ NMR spectrum $(300 \mathrm{MHz}, 330 \mathrm{~K})$ of 9. 


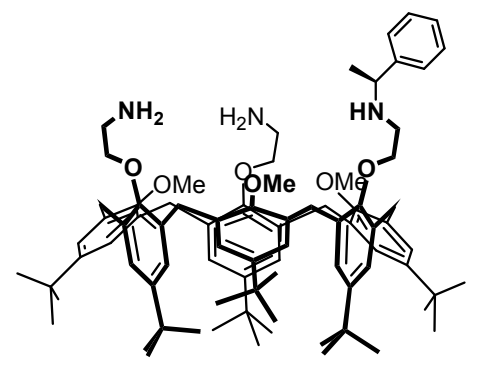

10

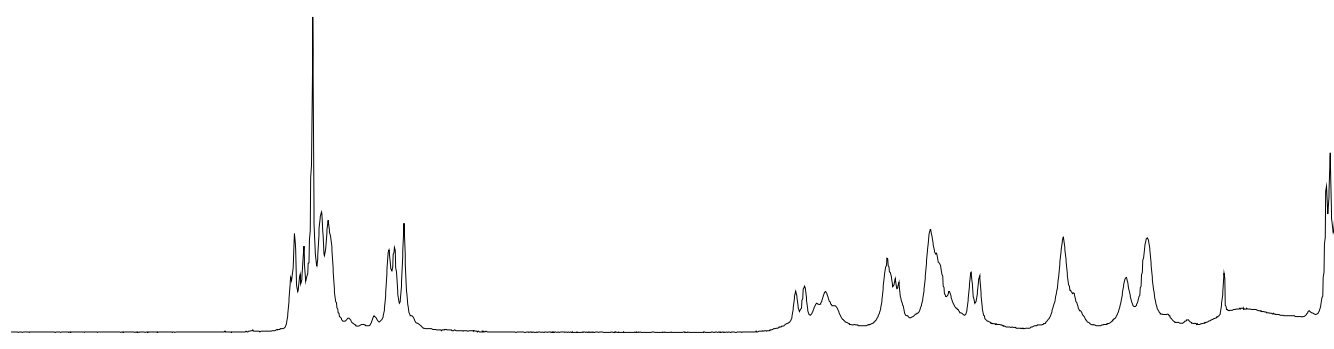

$\begin{array}{lllllllllllllllll}8.5 & 8.0 & 7.5 & 7.0 & 6.5 & 6.0 & 5.5 & 5.0 & 4.5 & 4.0 & 3.5 & 3.0 & 2.5 & 2.0 & 1.5 & 1.0 & 0.5\end{array}$ (ppm)

Figure S7. ${ }^{1} \mathrm{H}$ NMR spectrum ( $300 \mathrm{MHz}, \mathrm{rt}$ ) of $\mathbf{1 0}$. 


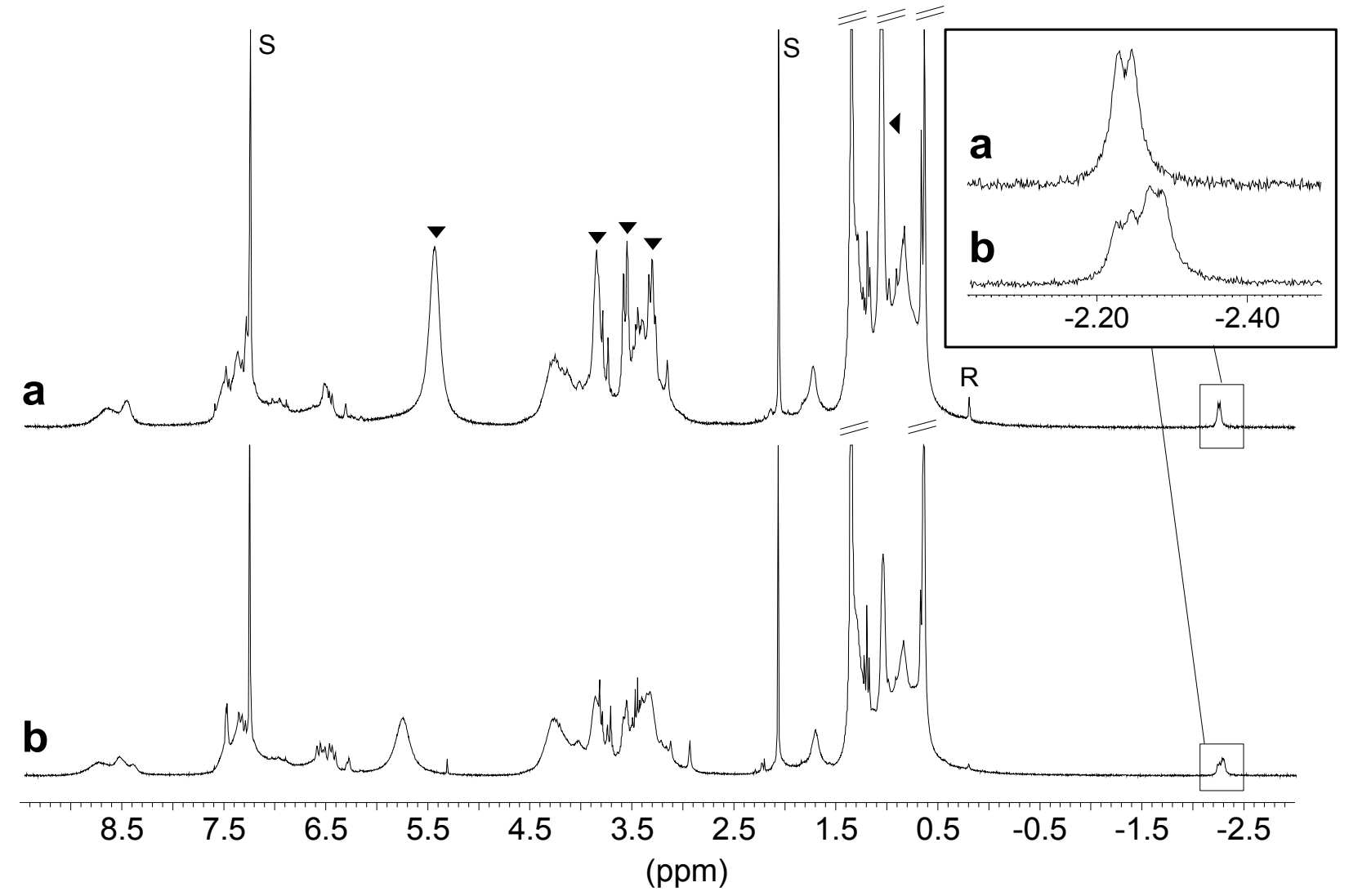

Figure S8. ${ }^{1} \mathrm{H}$ NMR spectra (300 MHz, $223 \mathrm{~K}$ ) of a: $\mathbf{1 0 \cdot 3 \mathbf { H } ^ { + }} \supset(-)$-propane-1,2-diol; b:10•3. $\mathbf{H}^{+} \supset(\mathbf{\pm})-$ propane-1,2-diol. Residual solvents and reference are labeled $\mathrm{S}$ and $\mathrm{R}$ respectively. $\boldsymbol{\nabla}$ : free propane-1,2-diol. 


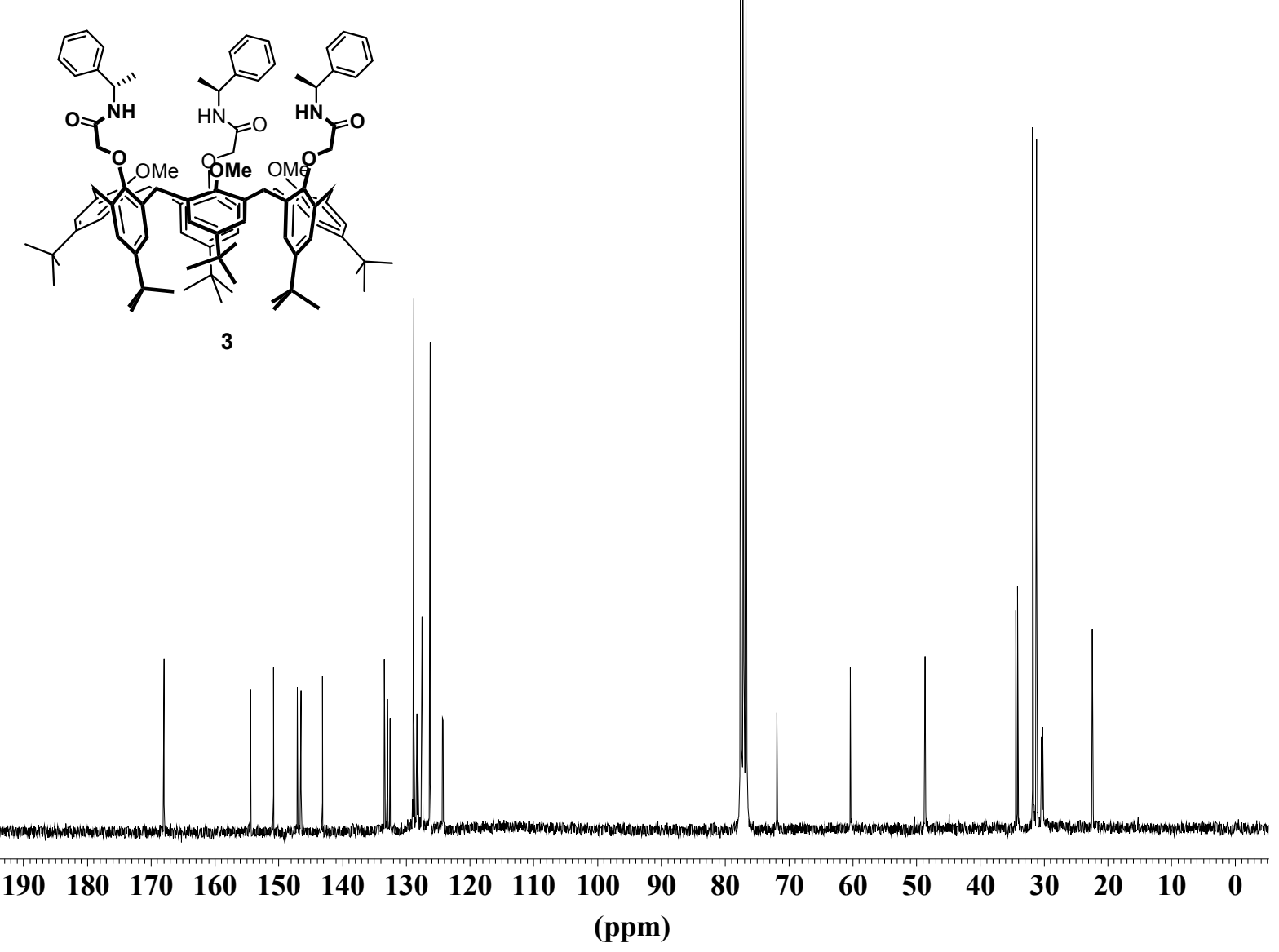

Figure S9. ${ }^{13} \mathrm{C}$ NMR spectrum $(75 \mathrm{MHz}, \mathrm{rt})$ of 3. 


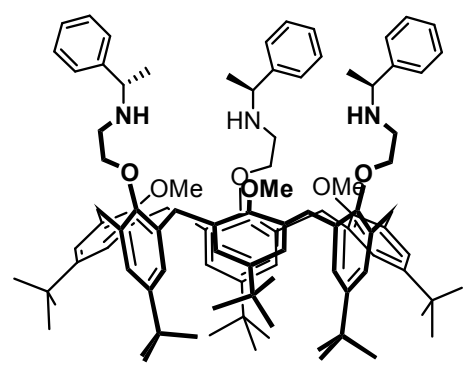

4

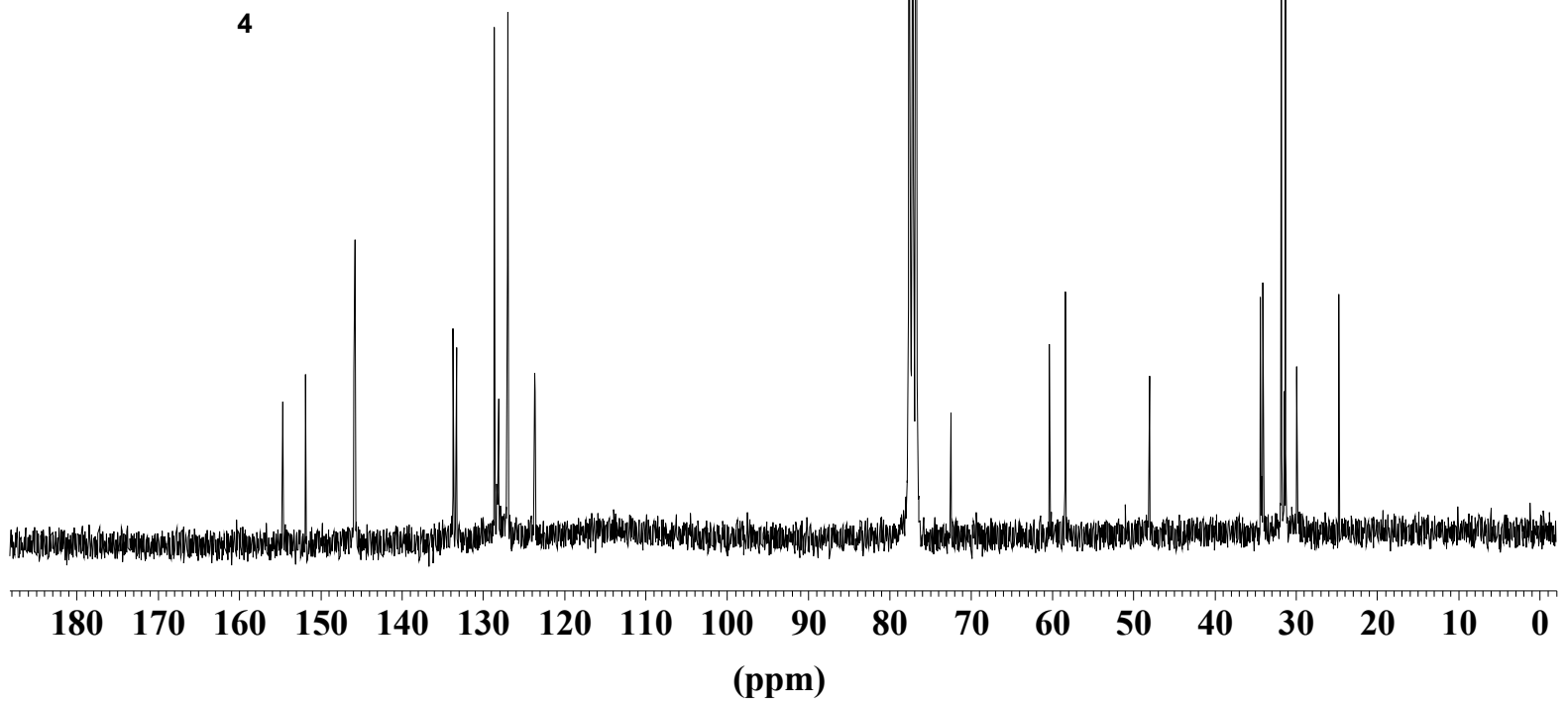

Figure S10. ${ }^{13} \mathrm{C}$ NMR spectrum $(75 \mathrm{MHz}, \mathrm{rt})$ of 4. 


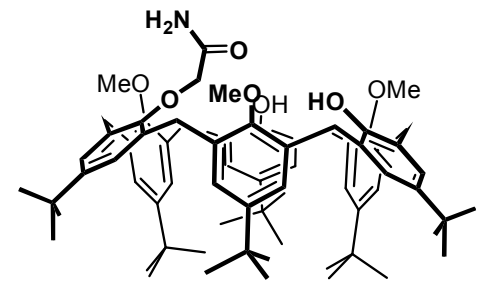

5

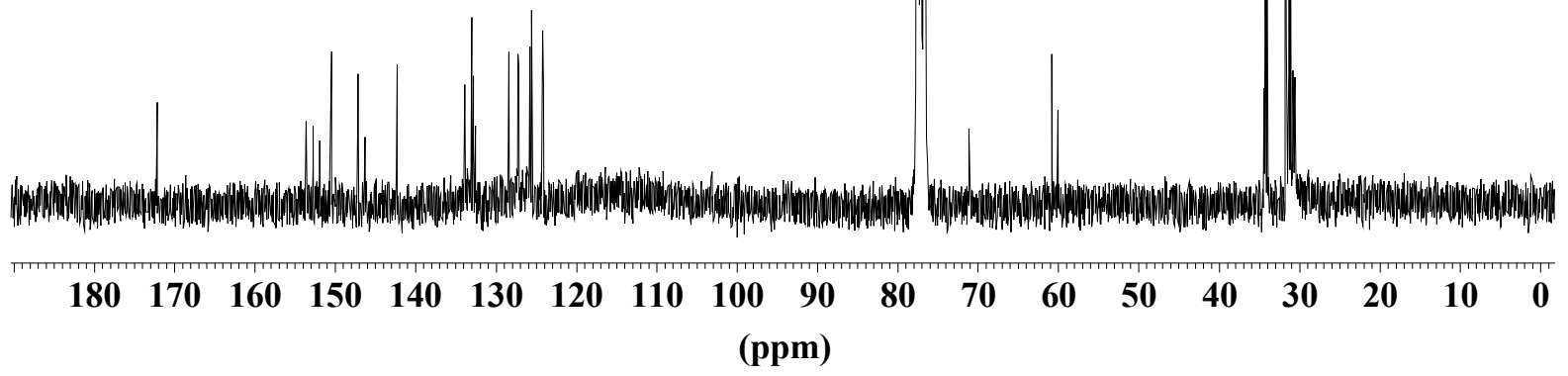

Figure S11. ${ }^{13} \mathrm{C}$ NMR spectrum $(75 \mathrm{MHz}, \mathrm{rt})$ of 5 . 


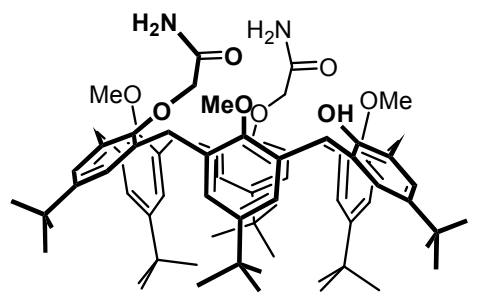

8

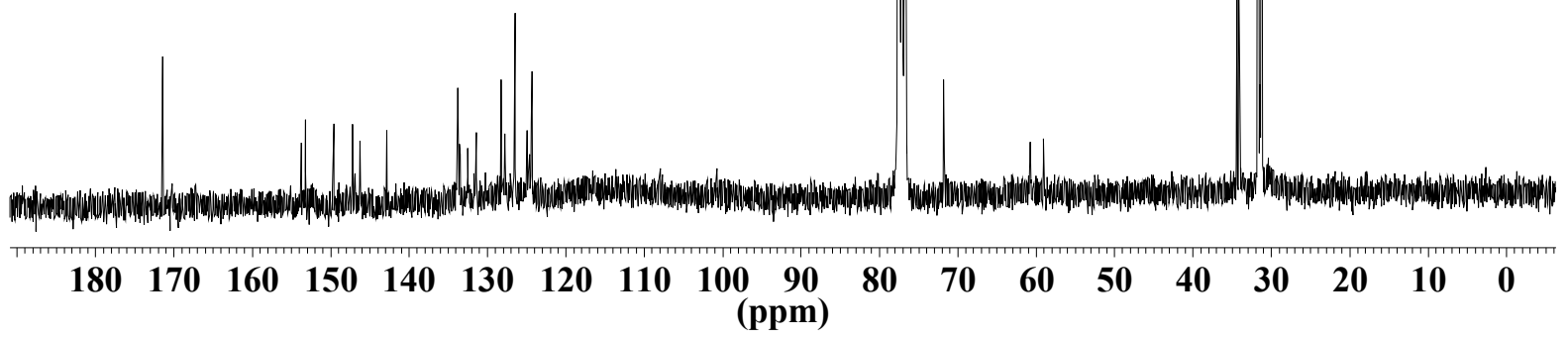

Figure S12. ${ }^{13} \mathrm{C}$ NMR spectrum $(75 \mathrm{MHz}, \mathrm{rt})$ of 8 . 


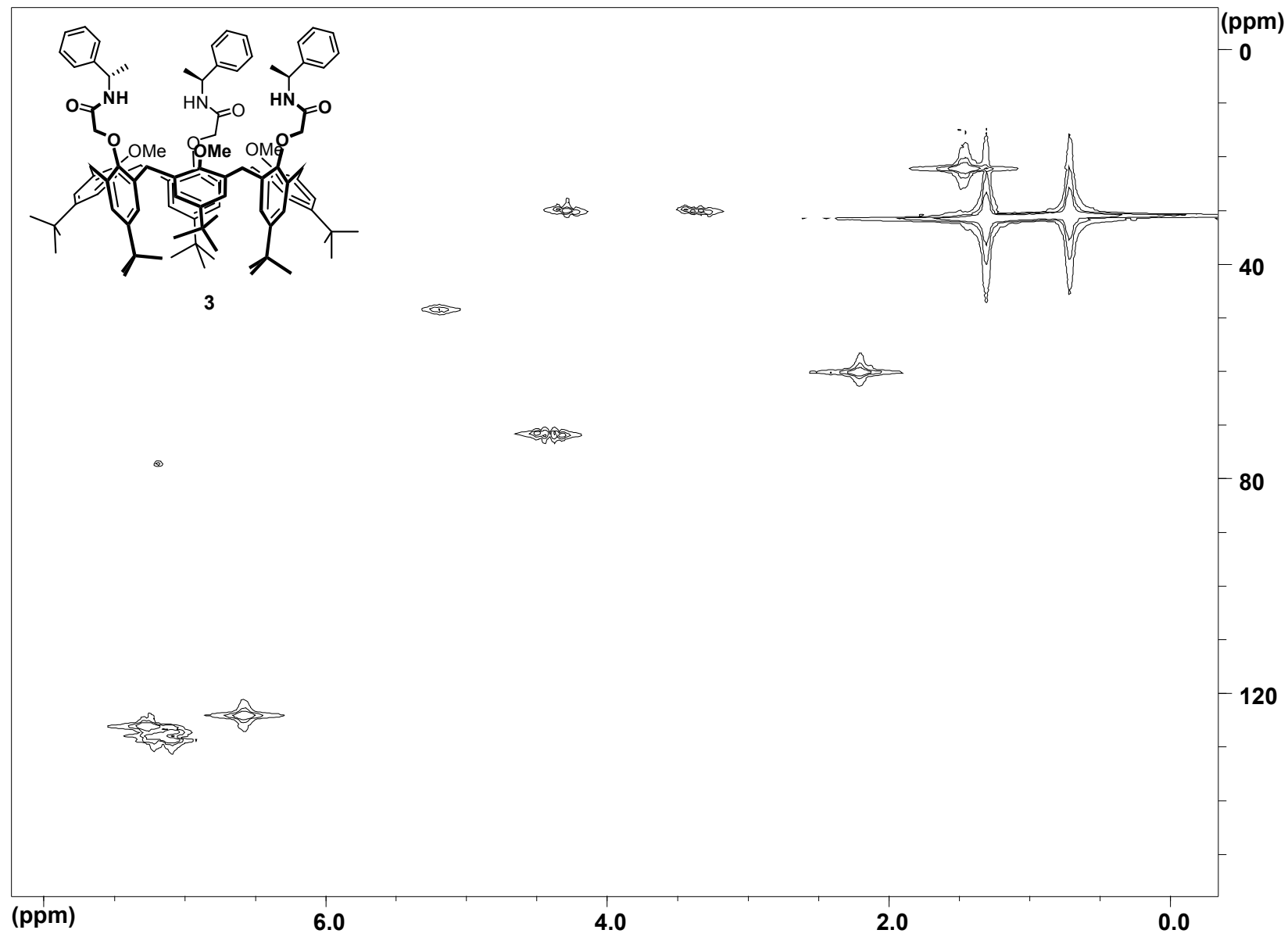

Figure S13. HMQC spectrum (300 MHz, rt) of 3. 


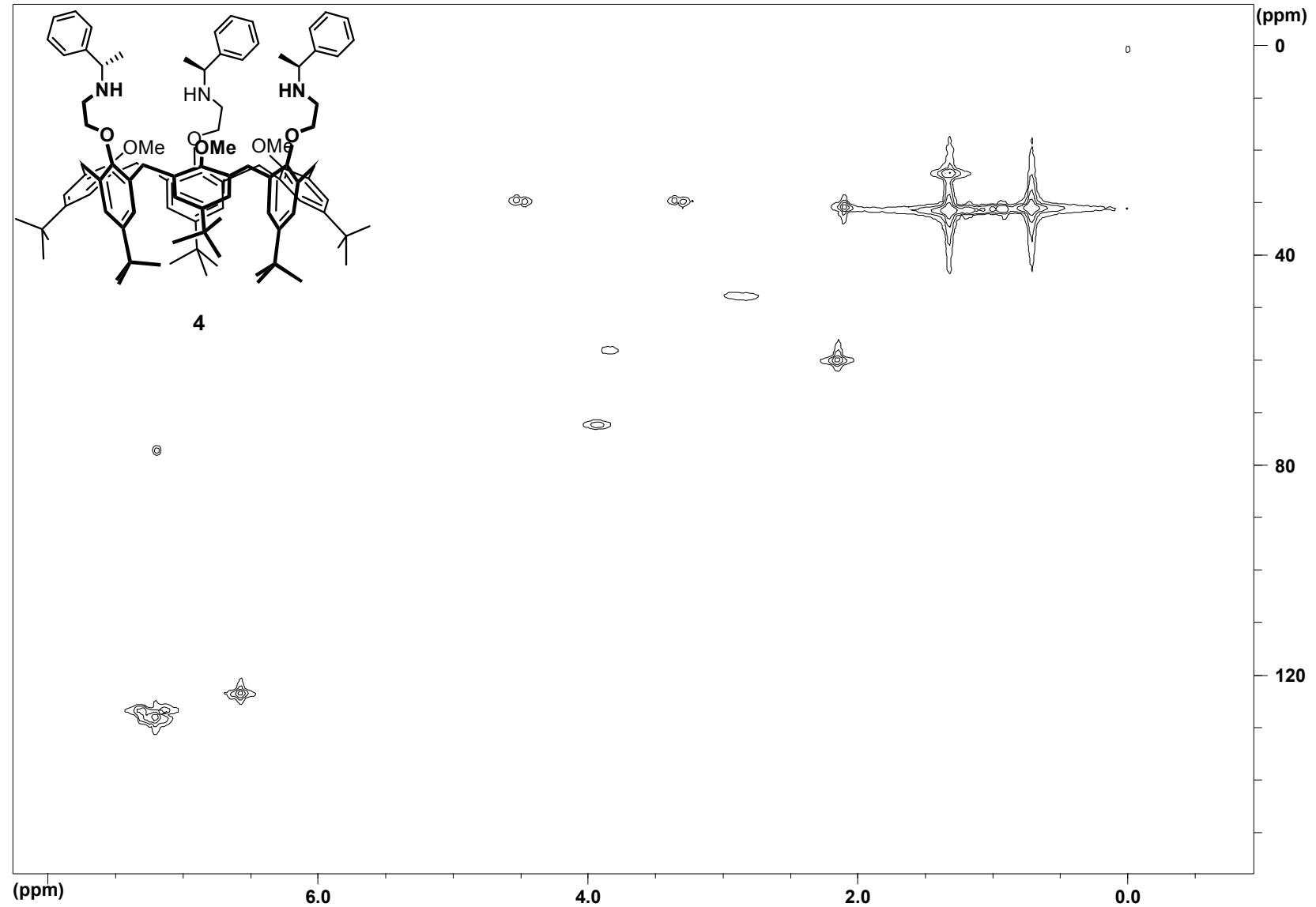

Figure S14. HMQC spectrum (300 MHz, rt) of 4. 


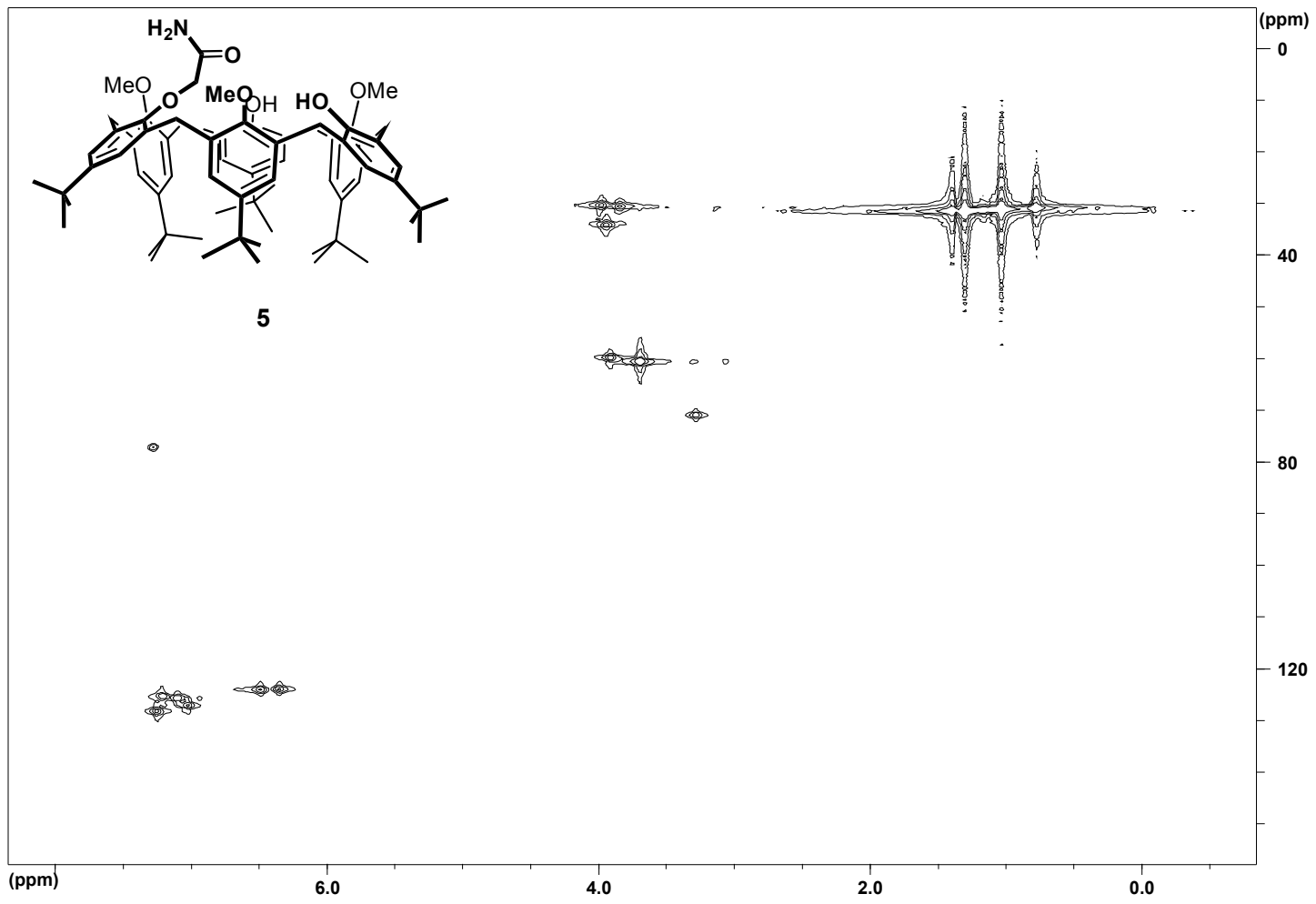

Figure S15. HMQC spectrum (300 MHz, rt) of 5. 


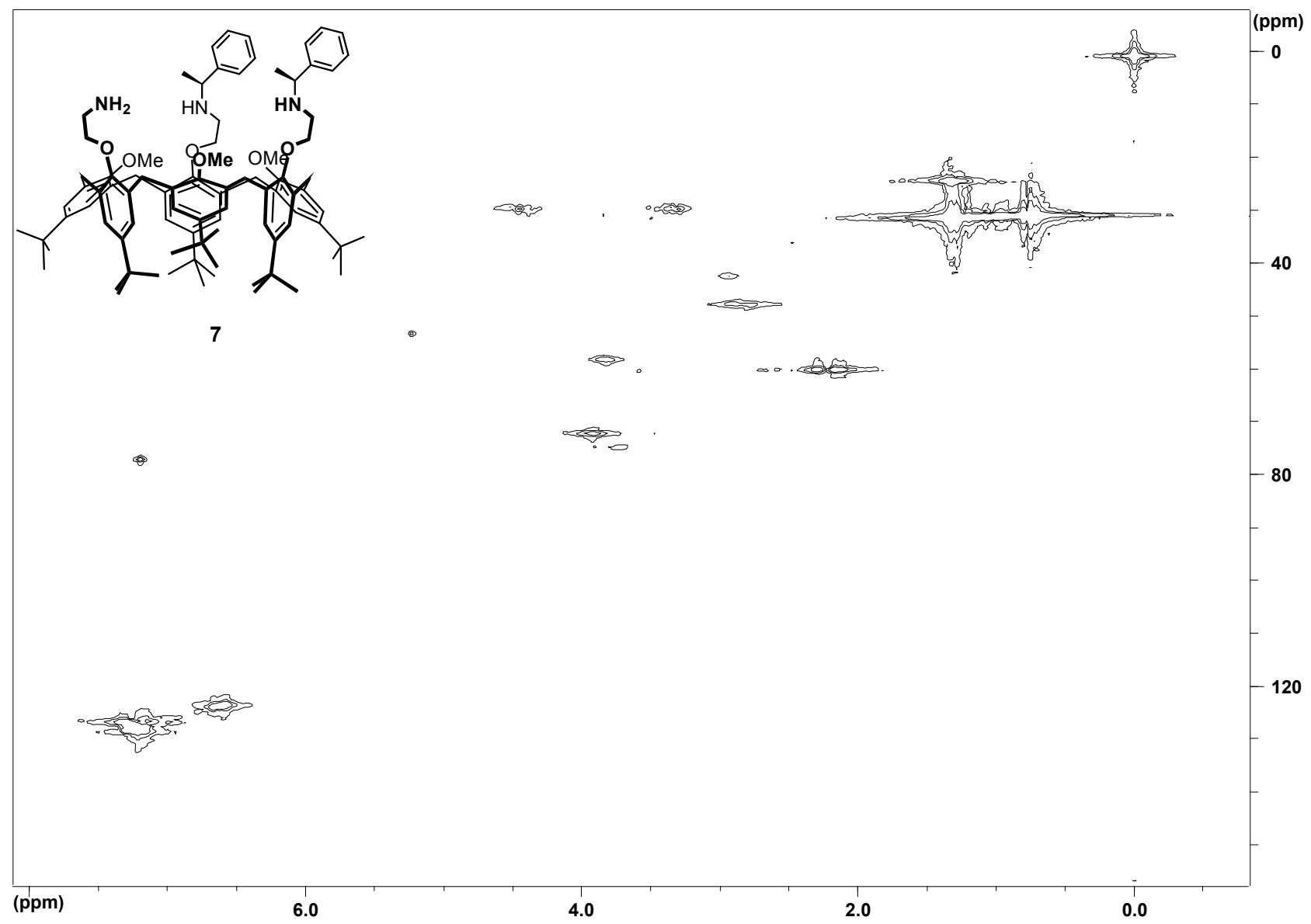

Figure S16. HMQC spectrum (300 MHz, rt) of 7. 


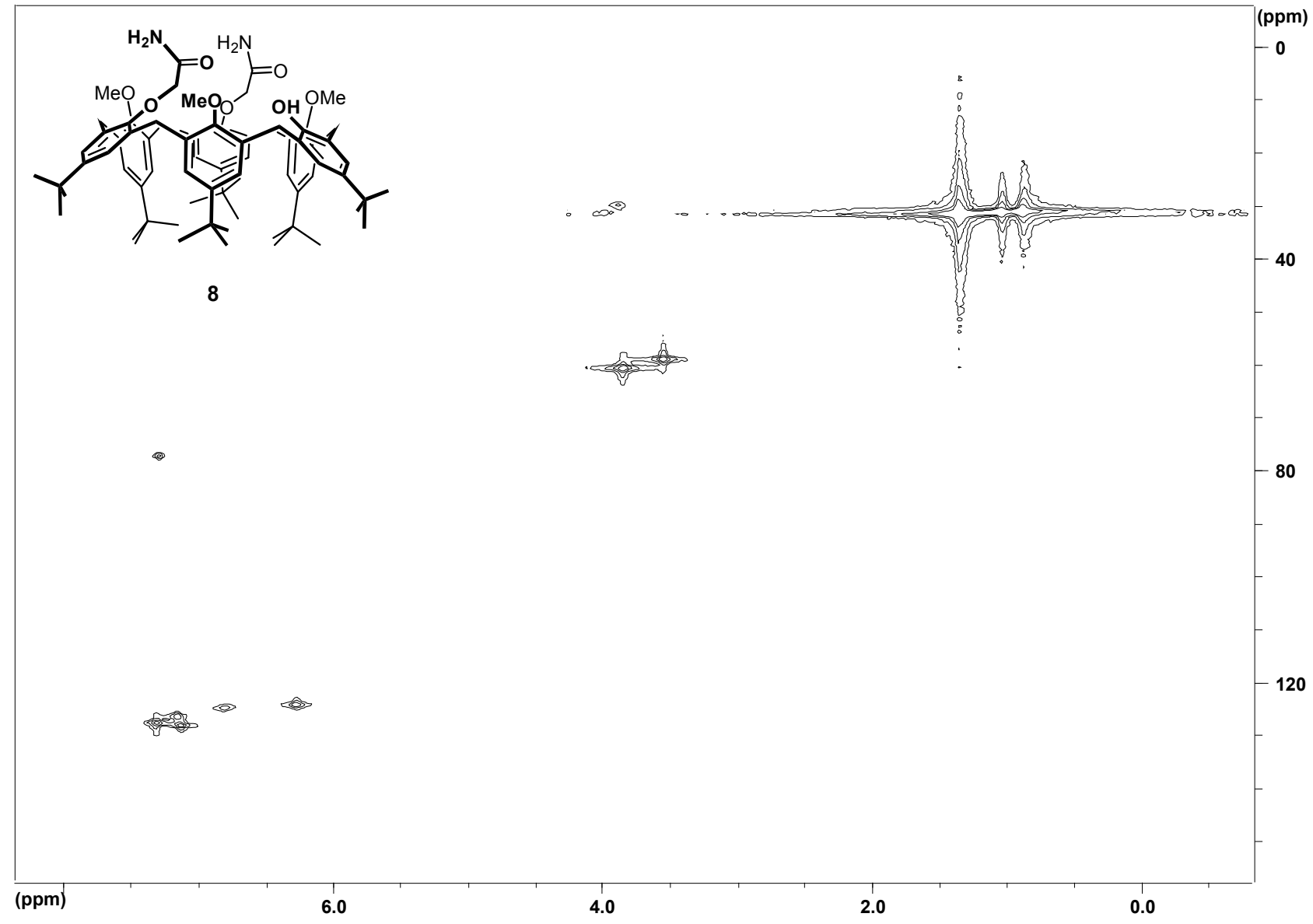

Figure S17. HMQC spectrum (300 MHz, rt) of 8. 


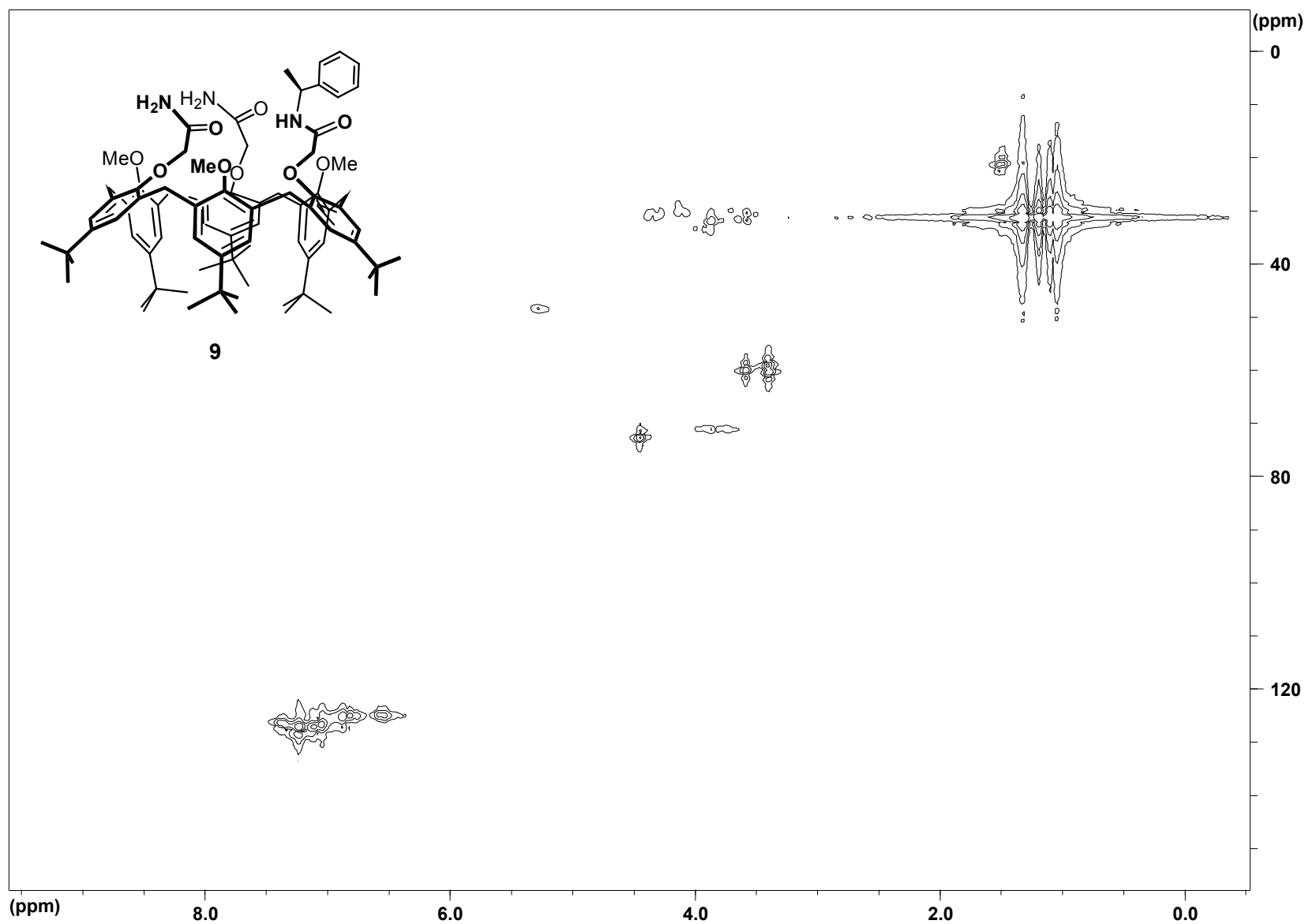

Figure S18. HMQC spectrum $(300 \mathrm{MHz}, 330 \mathrm{~K})$ of 9. 


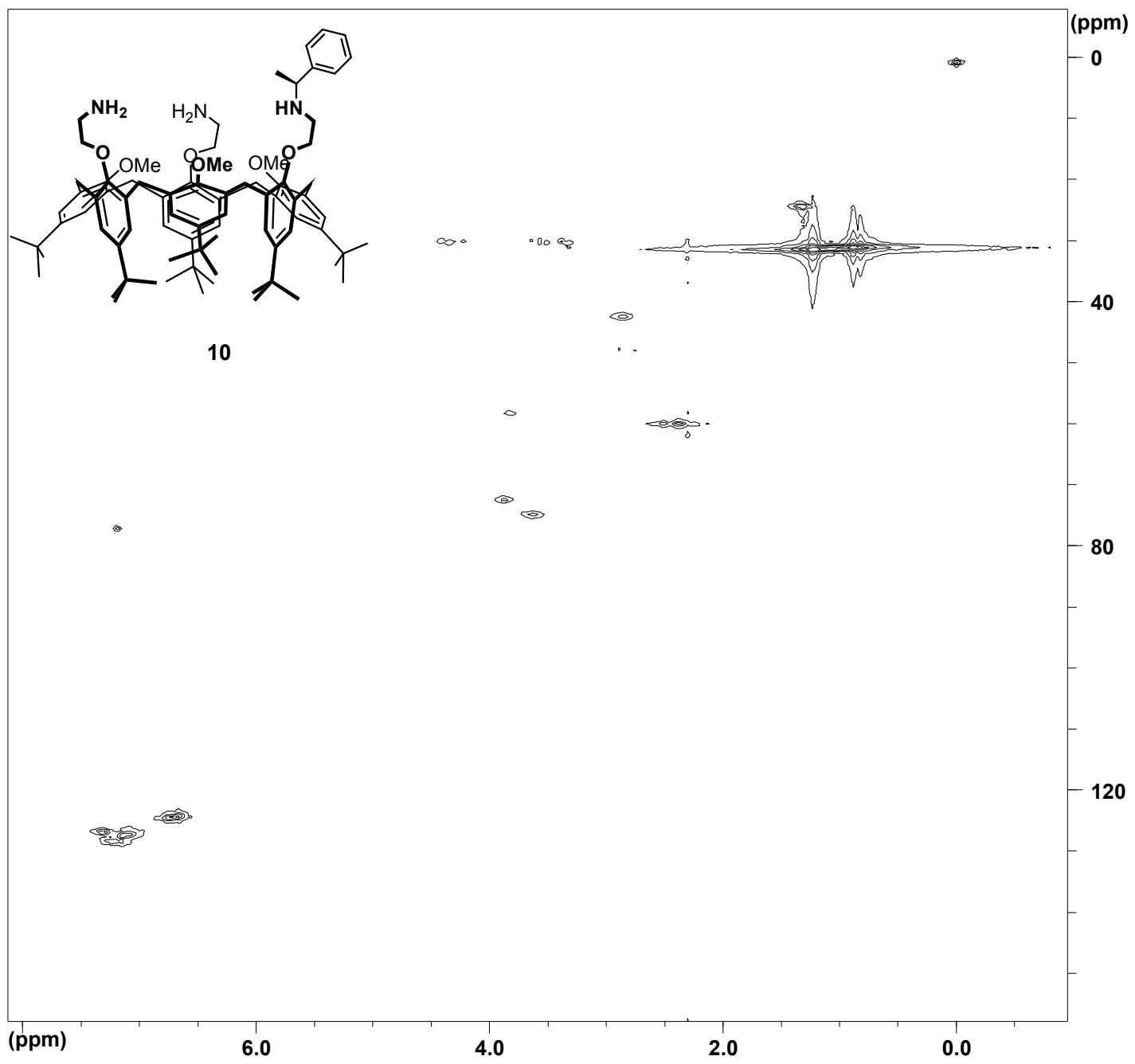

Figure S19. HMQC spectrum (300 MHz, rt) of 10. 

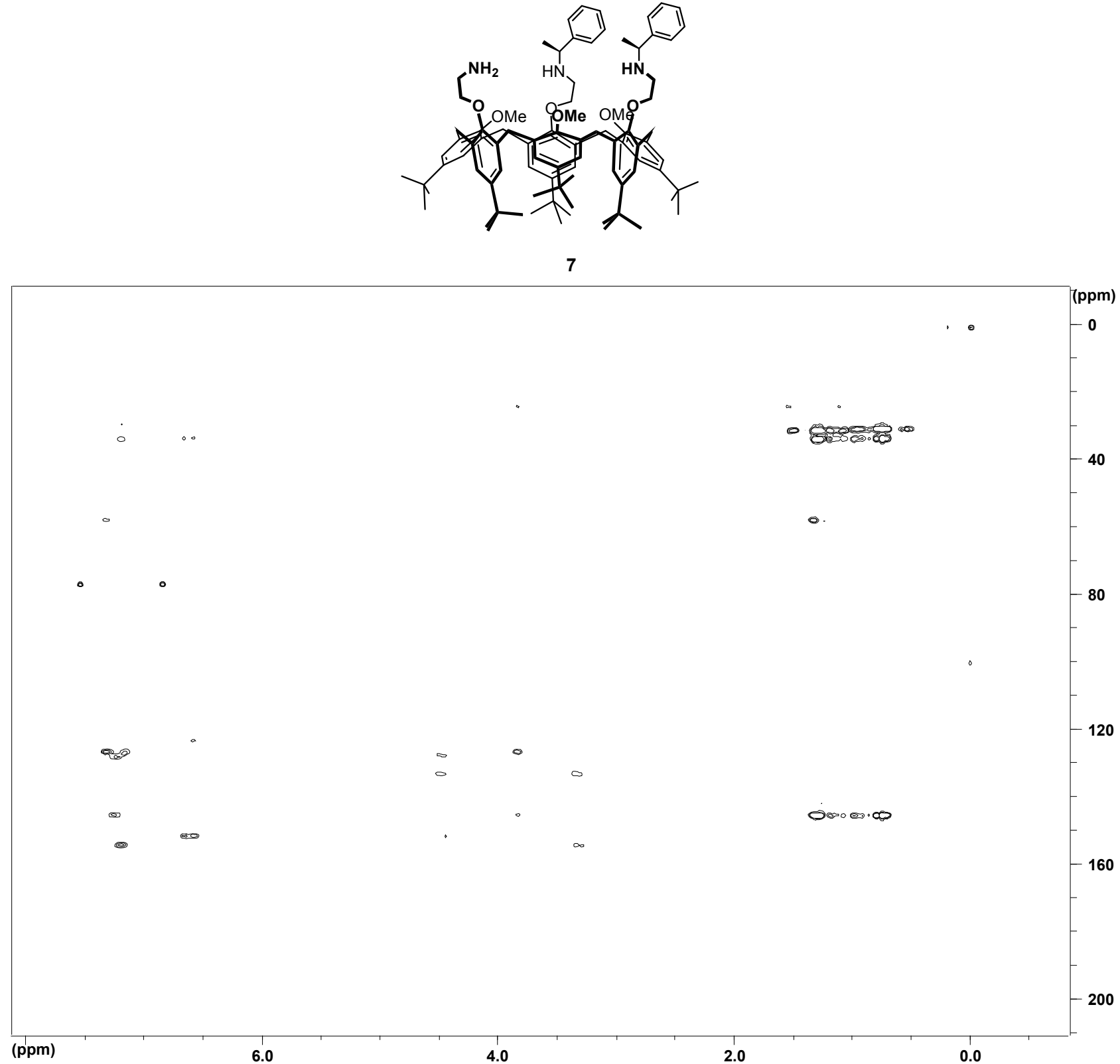

Figure S20. HMBC spectrum $(300 \mathrm{MHz}$, rt) of 7. 


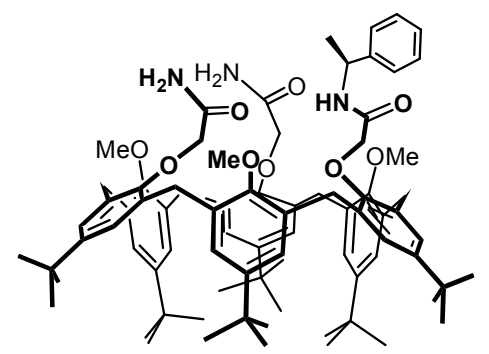

9

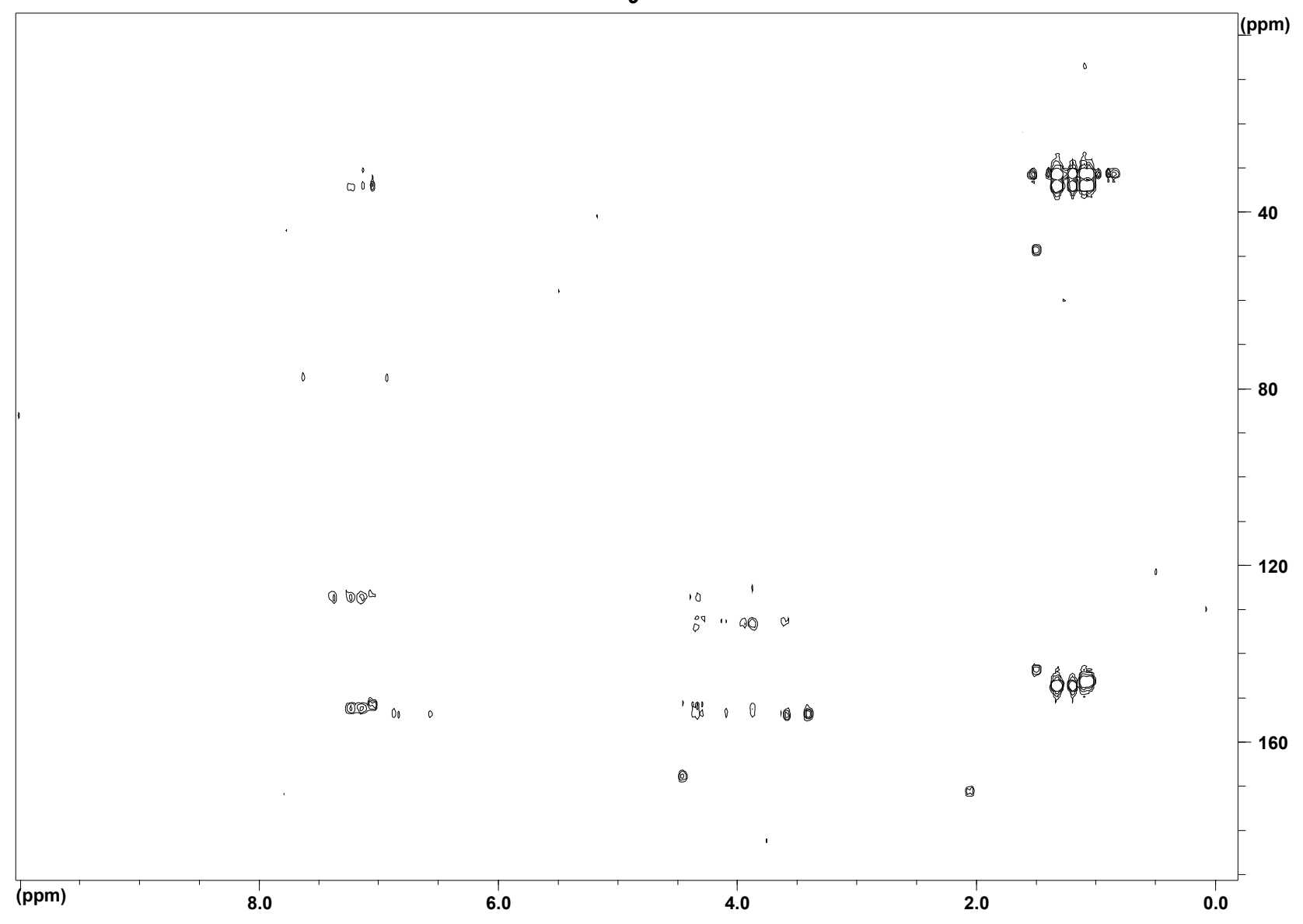

Figure S21. HMBC spectrum (300 MHz, $330 \mathrm{~K})$ of 9. 

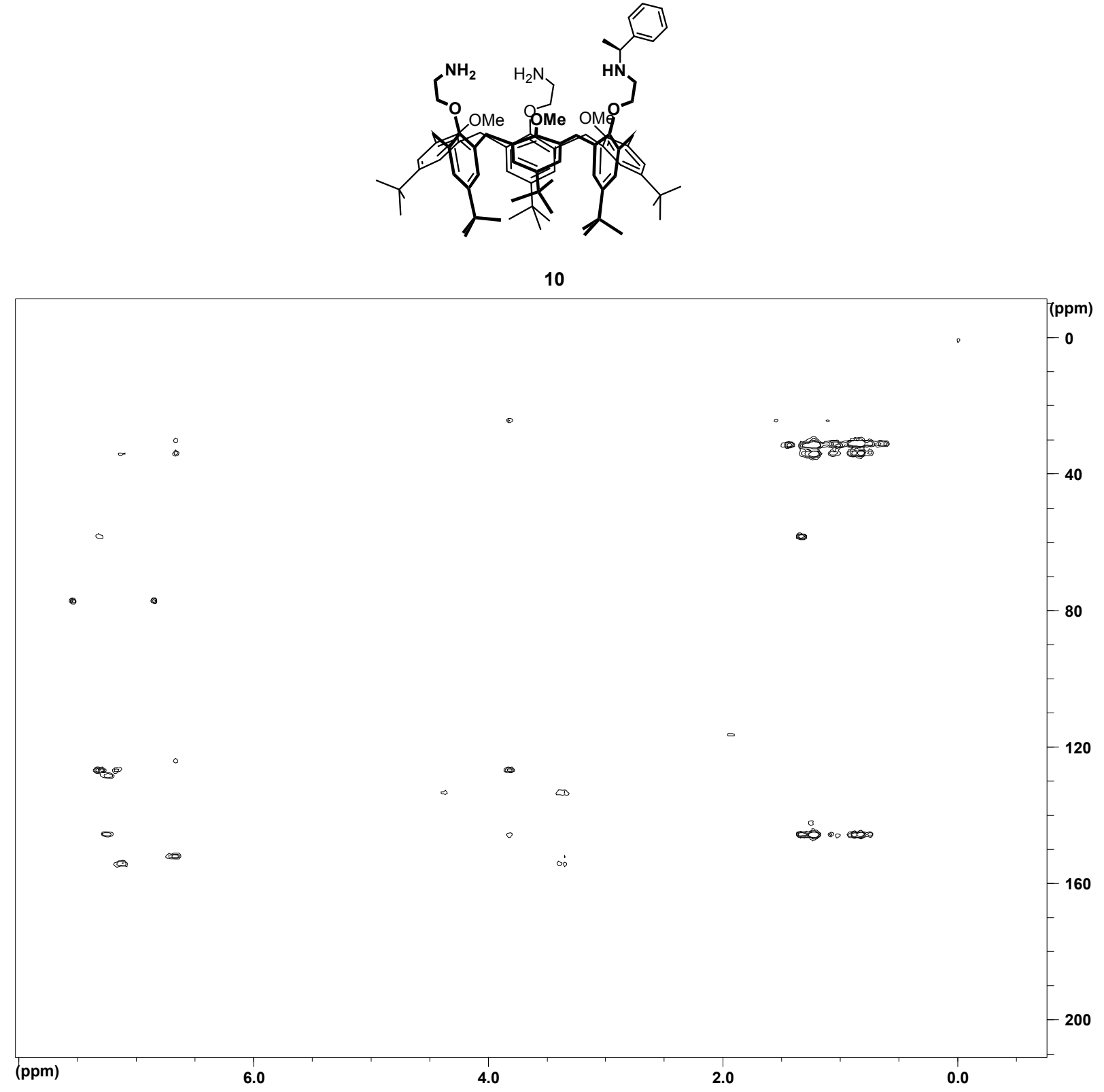

Figure S22. HMBC spectrum (300 MHz, rt) of 10. 

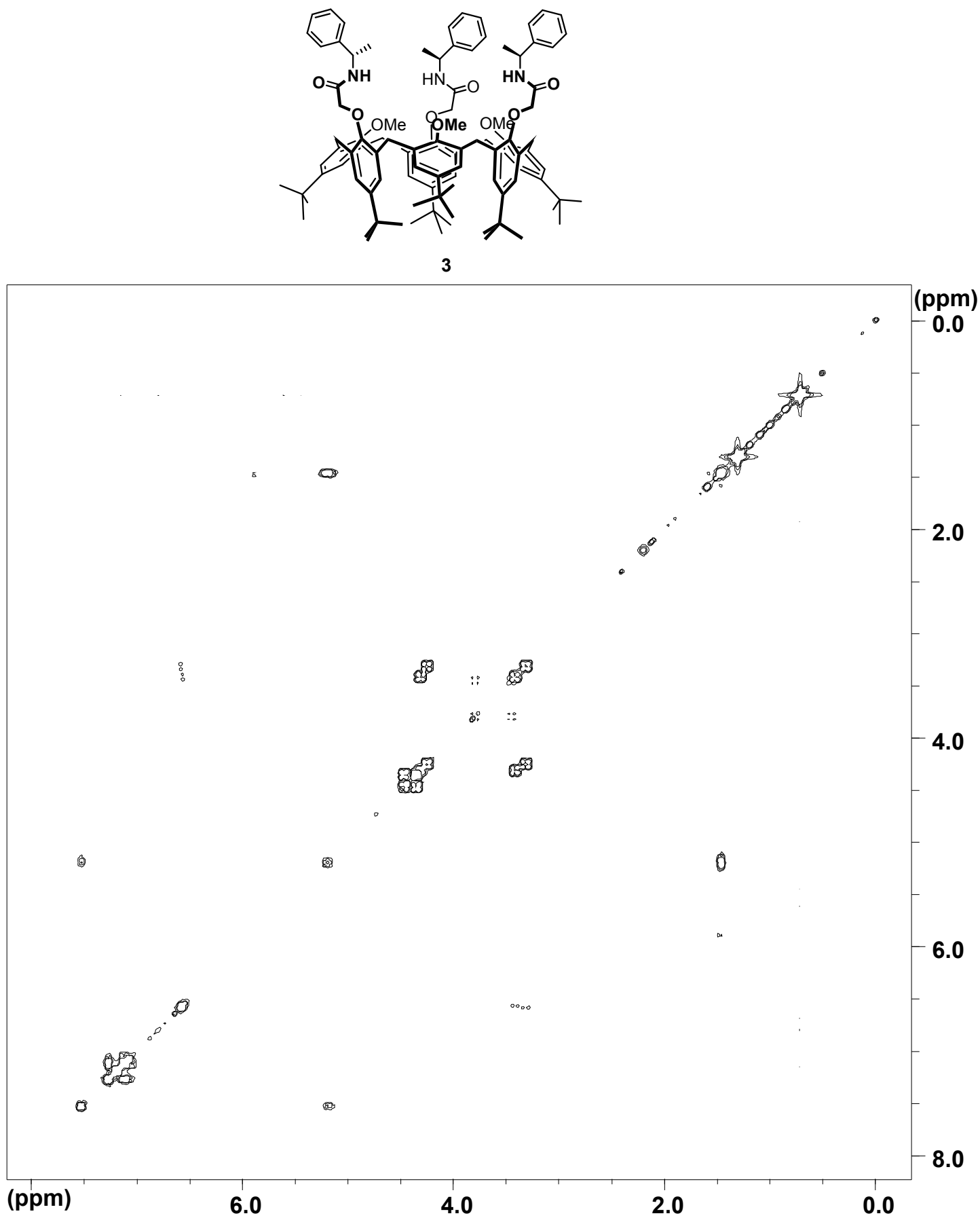

Figure S23. COSY spectrum (300 MHz, rt) of 3. 


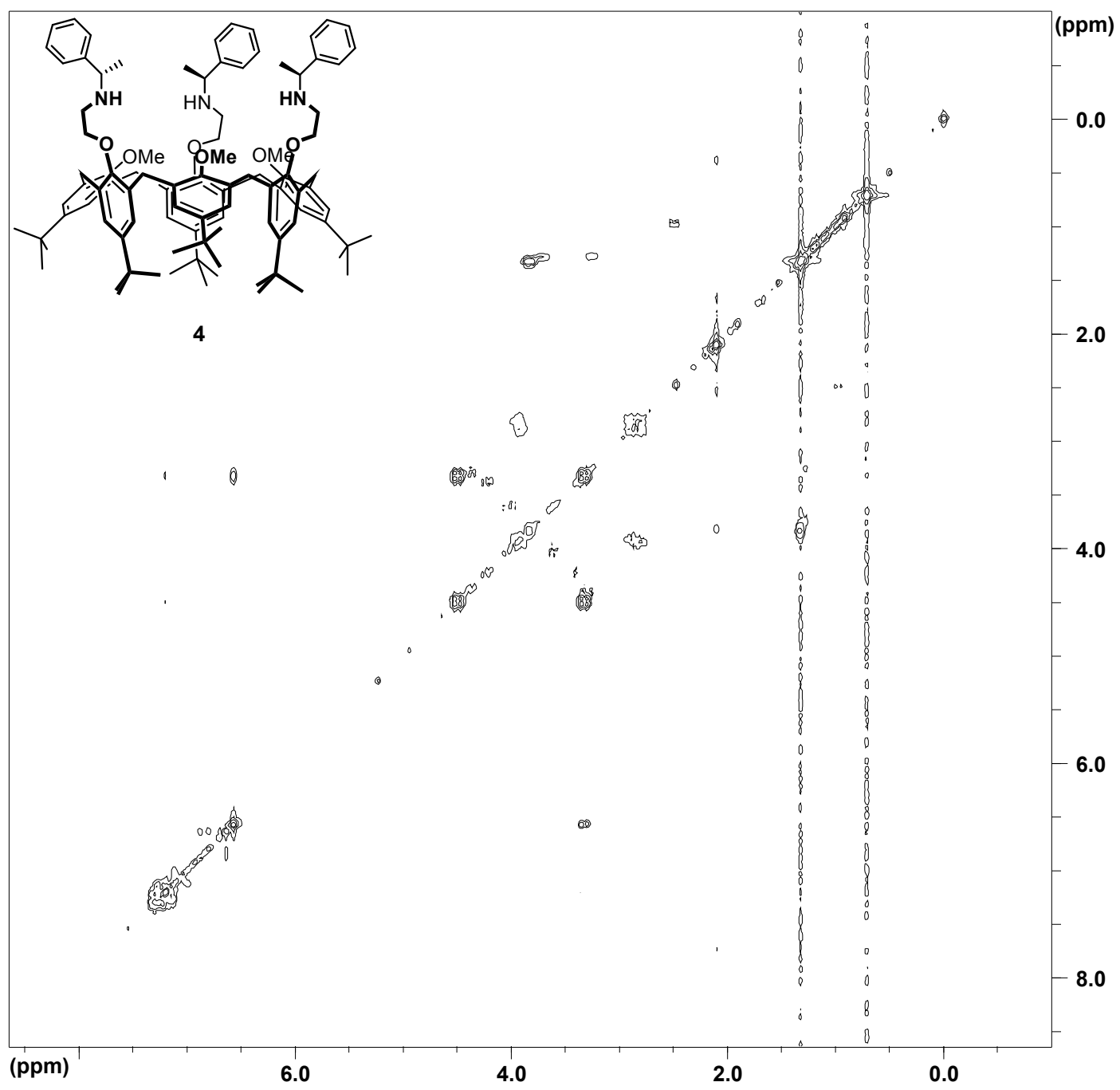

Figure S24. COSY spectrum (300 MHz, rt) of 4. 


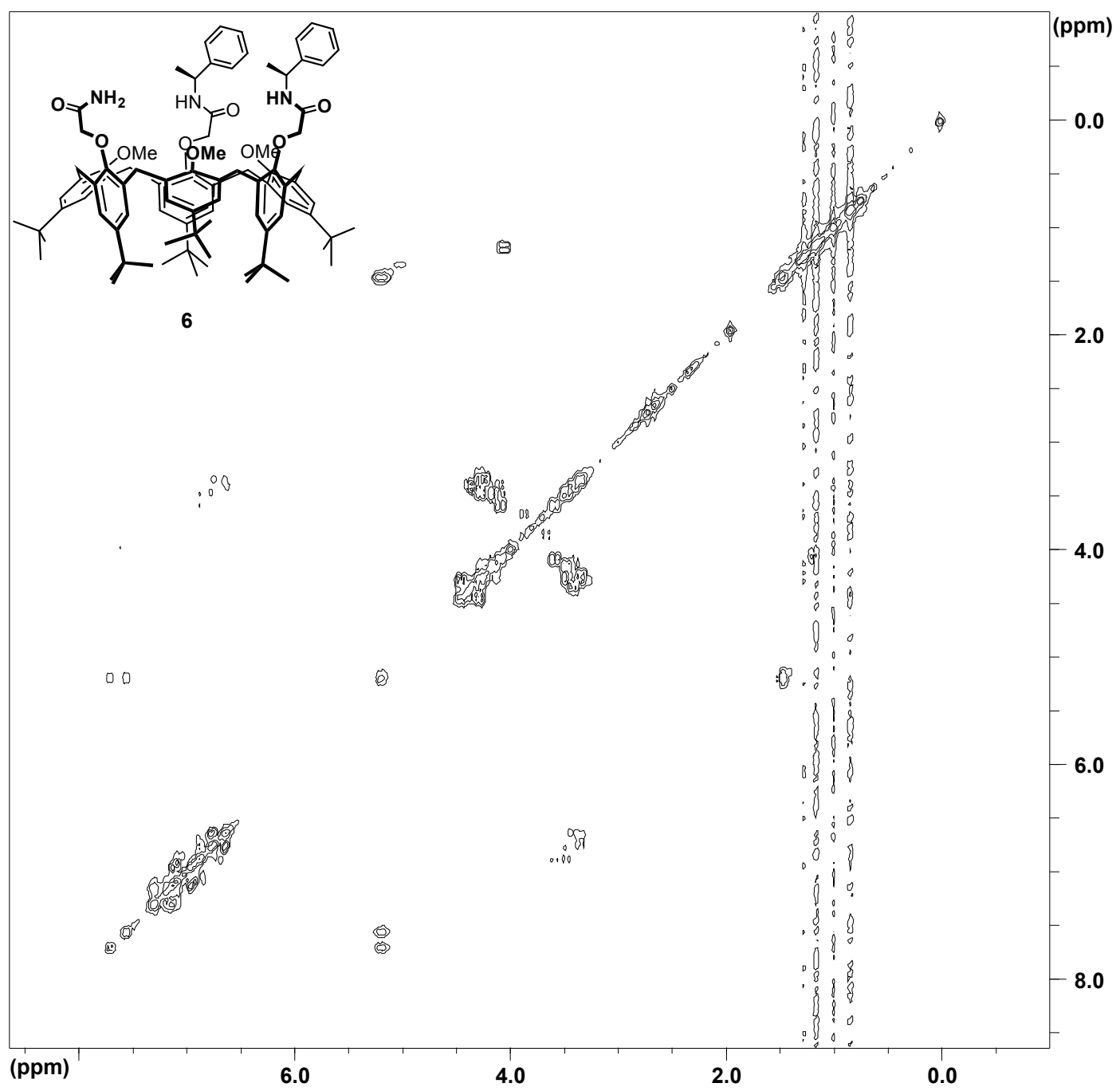

Figure S25. COSY spectrum (300 MHz, $330 \mathrm{~K})$ of 6. 


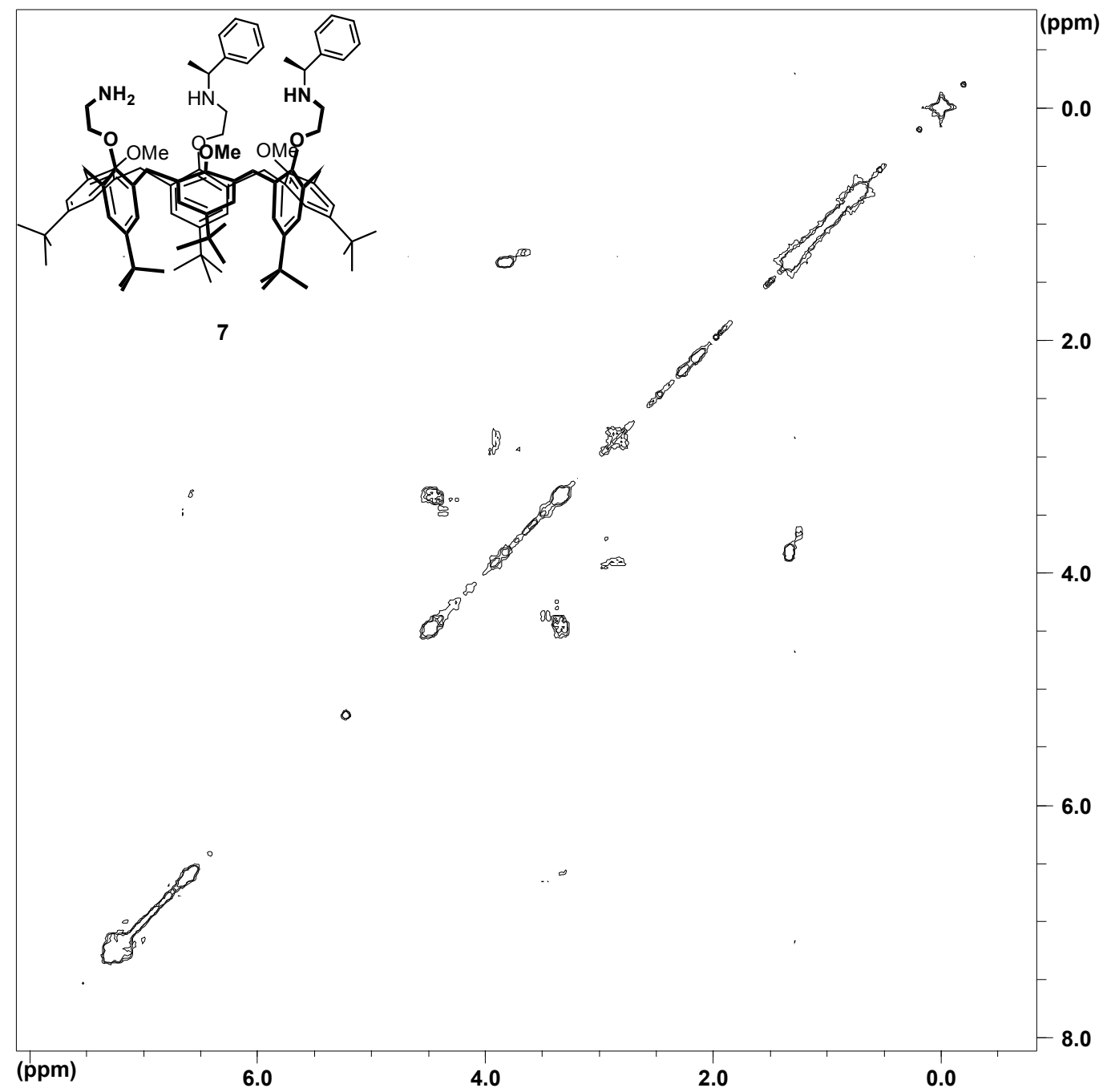

Figure S26. COSY spectrum (300 MHz, rt) of 7. 


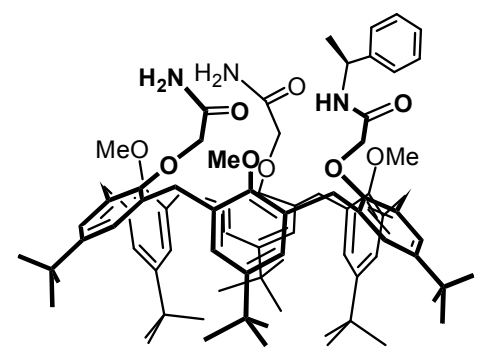

9

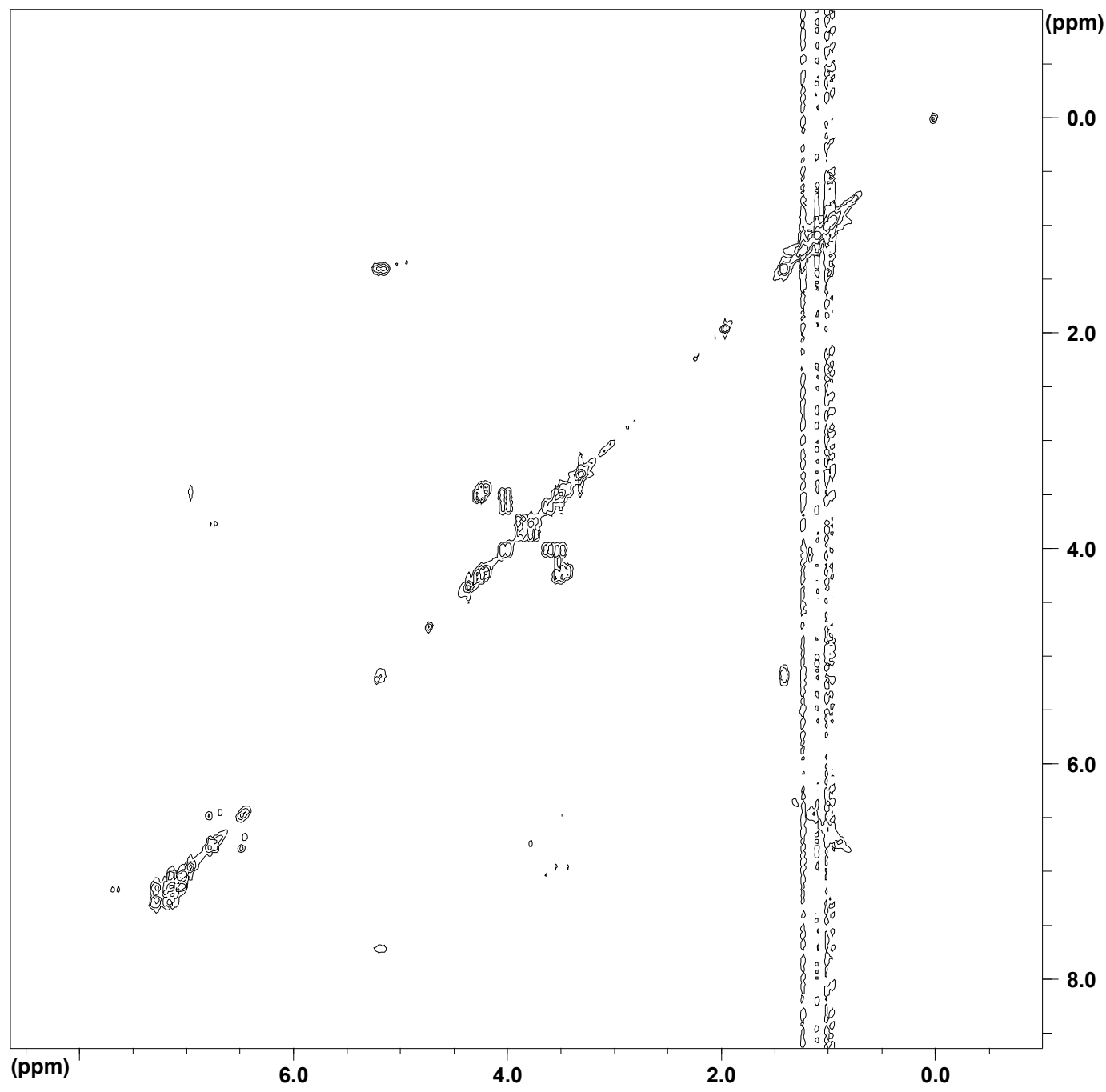

Figure S27. COSY spectrum (300 MHz, $330 \mathrm{~K})$ of 9. 


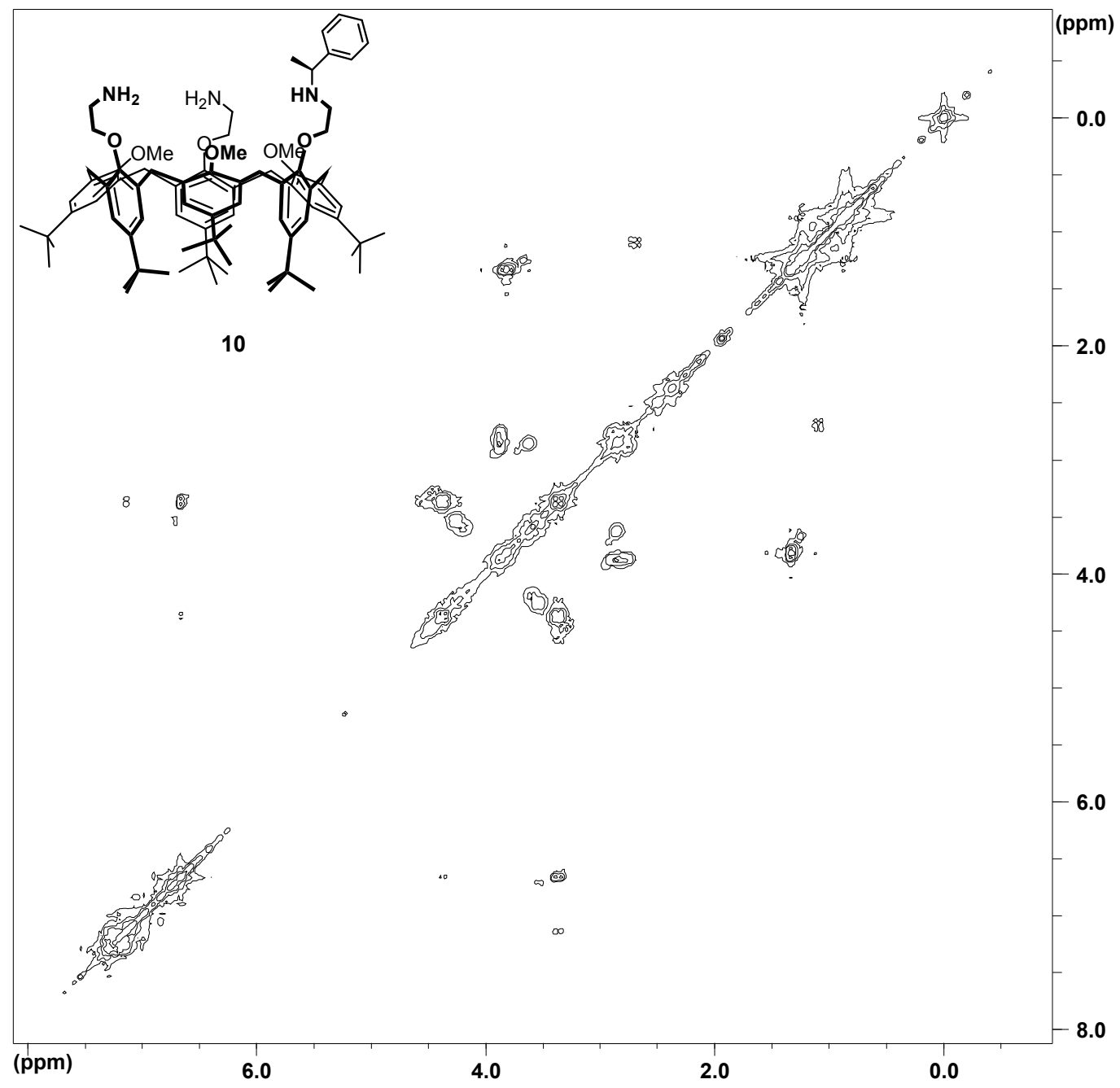

Figure S28. COSY spectrum (300 MHz, rt) of $\mathbf{1 0 .}$ 

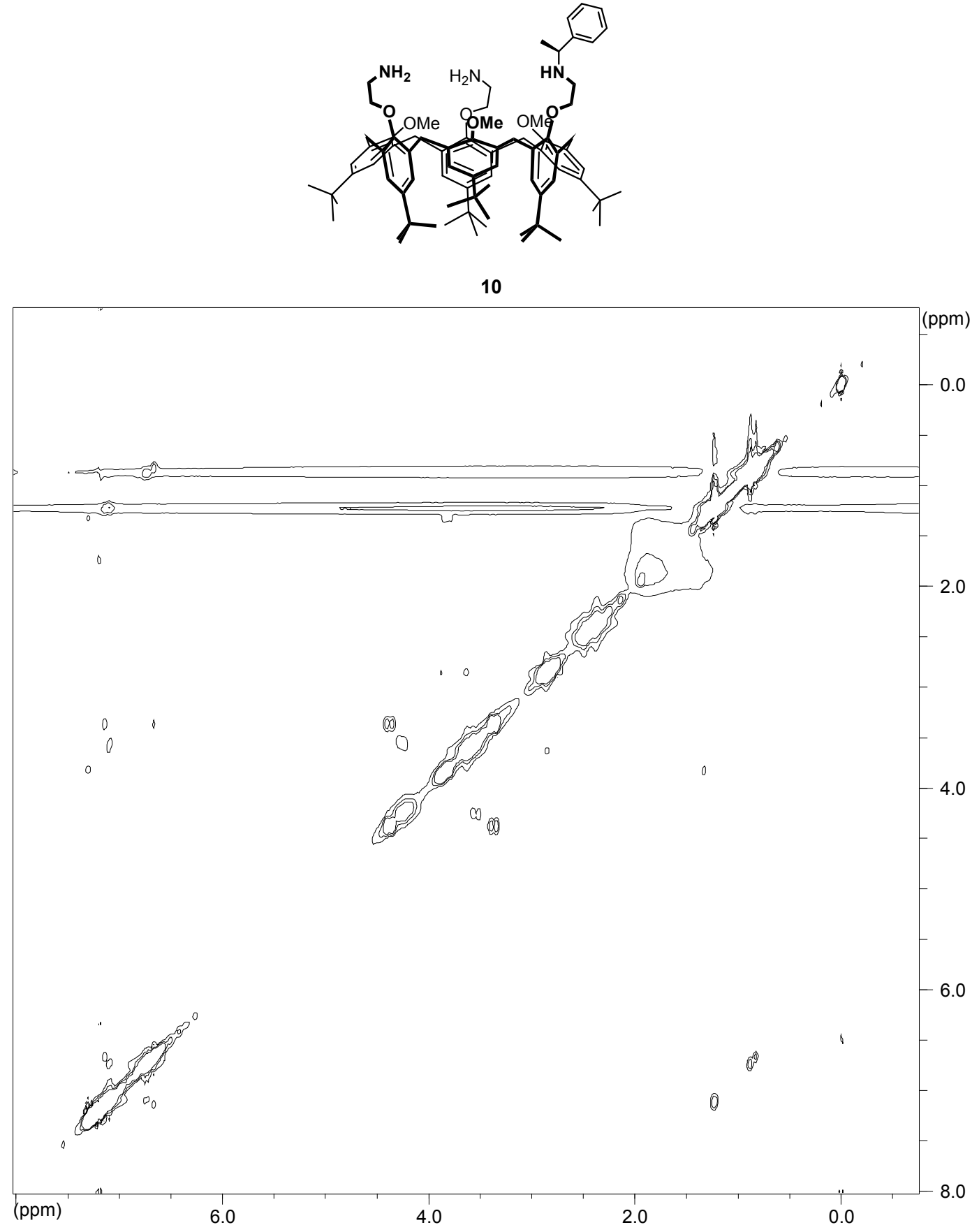

Figure S29. NOESY spectrum $(300 \mathrm{MHz}, \mathrm{rt})$ of $\mathbf{1 0}$. 


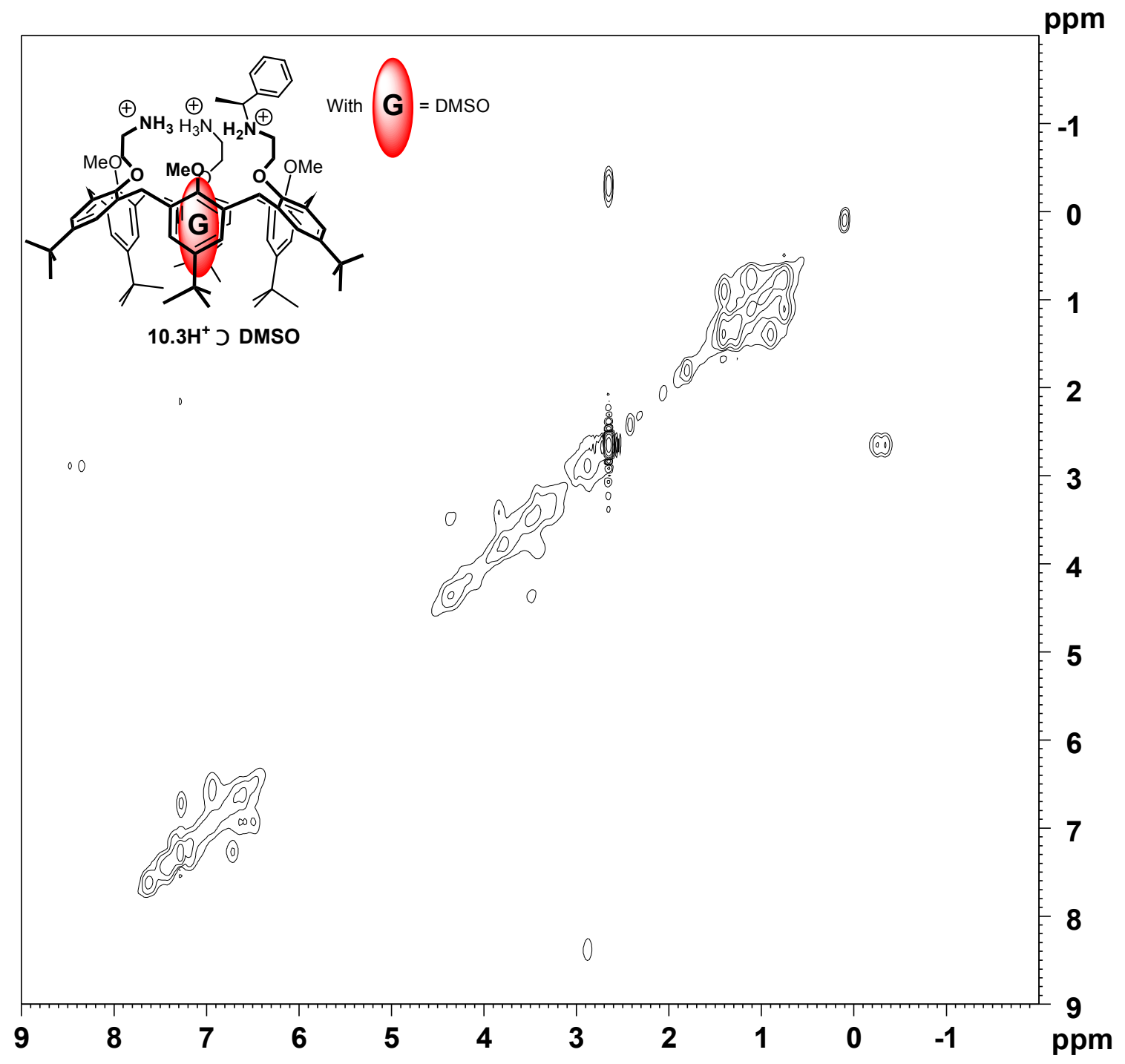

Figure S30. NOESY spectrum $(300 \mathrm{MHz}, \mathrm{rt})$ of $\mathbf{1 0 \bullet 3 H ^ { + }} \supset \mathbf{D M S O}$. 


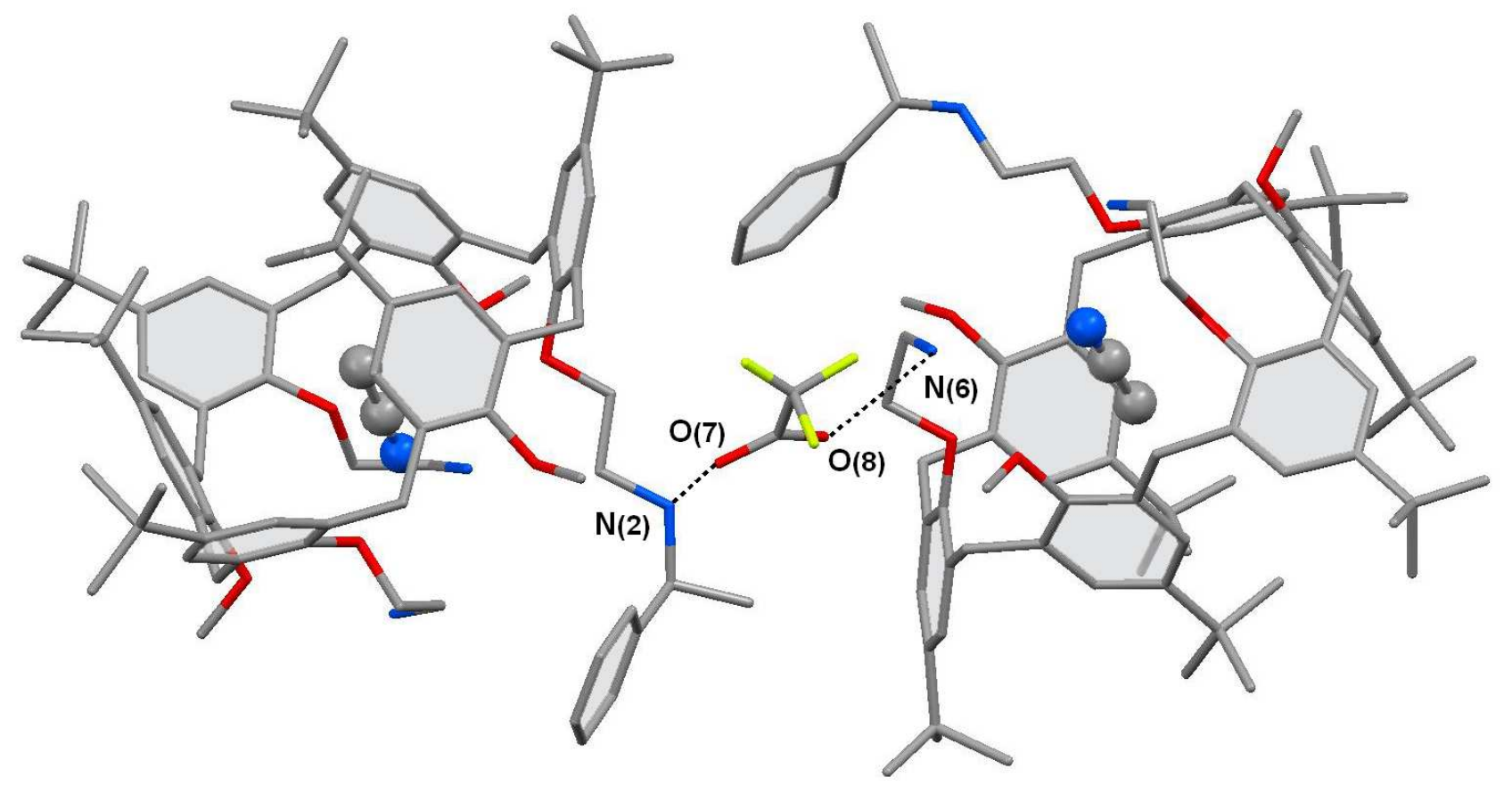

Figure S31. Crystal structure of $\mathbf{1 0} \cdot 3 \mathbf{H}^{+} \supset \mathbf{C H}_{3} \mathbf{C N}$ displaying the main intermolecular H-bond interactions within the unit cell. Hydrogen atoms, some trifluoroacetate anions, some crystallization solvent molecules have been omitted for clarity. Hydrogen bond distances $(\AA)$ : $\mathrm{N}(6){ }^{\cdots} \mathrm{O}(8)=2.746$, $\mathrm{N}(2) \cdots \mathrm{O}(7)=2.800$. 
General Experimental Procedures. THF was distilled over sodium/benzophenone under argon. $\mathrm{CH}_{2} \mathrm{Cl}_{2}$ was distilled over $\mathrm{CaH}_{2}$ under argon. DMF was distilled over $\mathrm{SiO}_{2} / \mathrm{MgSO}_{4}$ under argon. Ethanol was distilled over sodium/diethylphthalate under argon. All reactions were performed under an inert atmosphere. Silica gel (230-400 mesh) was used for flash chromatography separations. ${ }^{1} \mathrm{H}$ and ${ }^{13} \mathrm{C}$ NMR spectra were recorded, respectively, at $300 \mathrm{MHz}$ and $75 \mathrm{MHz}$. Traces of residual solvent or poly(dimethylsiloxane) (R) were used as internal standard. Chemical shifts are expressed in ppm. ${ }^{1} \mathrm{H}$ resonances corresponding to the aromatic moities of the calixarene core and of the phenylethylamine group are labelled respectively $\mathrm{ArH}_{\text {calix }}$ and $\mathrm{ArH}_{\text {phe }}$. 